\title{
Article \\ Cruciate Ligament Cell Sheets Can Be Rapidly Produced on Thermoresponsive poly(glycidyl ether) Coating and Successfully Used for Colonization of Embroidered Scaffolds
}

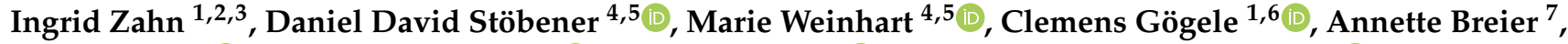 \\ Judith Hahn ${ }^{7} \mathbb{D}$, Michaela Schröpfer ${ }^{8} \mathbb{D}$, Michael Meyer $^{8} \mathbb{D}$ and Gundula Schulze-Tanzil ${ }^{1, *(\mathbb{D})}$
}

1 Institute of Anatomy and Cell Biology, Paracelsus Medical University, Nuremberg and Salzburg, Prof. Ernst Nathan Str. 1, 90419 Nuremberg, Germany; ingrid.zahn@fau.de (I.Z.);

clemens.goegele@pmu.ac.at (C.G.)

2 Department of Applied Chemistry, Nuremberg Institute of Technology Georg Simon Ohm, Keßlerplatz 12, 90489 Nuremberg, Germany

3 Institute of Functional and Clinical Anatomy, Friedrich Alexander University, Erlangen-Nuremberg, Universitätsstr. 19, 91054 Erlangen, Germany

4 Institute of Chemistry and Biochemistry, Freie Universität Berlin, Takustrasse 3, 14195 Berlin, Germany; daniel.stoebener@fu-berlin.de (D.D.S.); marie.weinhart@fu-berlin.de (M.W.)

check for updates

Citation: Zahn, I.; Stöbener, D.D.; Weinhart, M.; Gögele, C.; Breier, A.; Hahn, J.; Schröpfer, M.; Meyer, M.; Schulze-Tanzil, G. Cruciate Ligament Cell Sheets Can Be Rapidly Produced on Thermoresponsive poly(glycidyl ether) Coating and Successfully Used for Colonization of Embroidered Scaffolds. Cells 2021, 10, 877. https://doi.org/10.3390/ cells10040877

Academic Editor:

Maddalena Mastrogiacomo

Received: 27 February 2021

Accepted: 7 April 2021

Published: 12 April 2021

Publisher's Note: MDPI stays neutral with regard to jurisdictional claims in published maps and institutional affiliations.

Copyright: (C) 2021 by the authors Licensee MDPI, Basel, Switzerland. This article is an open access article distributed under the terms and conditions of the Creative Commons Attribution (CC BY) license (https:/ / creativecommons.org/licenses/by/ $4.0 /)$.
5 Institute of Physical Chemistry and Electrochemistry, Leibniz Universität Hannover, Callinstr. 3A, 30167 Hannover, Germany

6 Department of Biosciences, Paris Lodron University Salzburg, Hellbrunnerstraße 34, 5020 Salzburg, Austria

7 Leibniz-Institut für Polymerforschung Dresden e. V. (IPF), Hohe Straße 6, 01069 Dresden, Germany; breier@ipfdd.de (A.B.); hahn-judith@ipfdd.de (J.H.)

8 FILK Freiberg Institute (FILK), Meißner Ring 1-5, 09599 Freiberg, Germany; michaela.schroepfer@filkfreiberg.de (M.S.); michael.meyer@filkfreiberg.de (M.M.)

* Correspondence: Gundula.schulze@pmu.ac.at; Tel.: +49-911-398-(11)-6772

Abstract: Anterior cruciate ligament (ACL) cell sheets combined with biomechanically competent scaffolds might facilitate ACL tissue engineering. Since thermoresponsive polymers allow a rapid enzyme-free detachment of cell sheets, we evaluated the applicability of a thermoresponsive poly(glycidyl ether) (PGE) coating for cruciate ligamentocyte sheet formation and its influence on ligamentocyte phenotype during sheet-mediated colonization of embroidered scaffolds. Ligamentocytes were seeded on surfaces either coated with PGE or without coating. Detached ligamentocyte sheets were cultured separately or wrapped around an embroidered scaffold made of polylactide acid (PLA) and poly(lactic-co- $\varepsilon$-caprolactone) (P(LA-CL)) threads functionalized by gas-phase fluorination and with collagen foam. Ligamentocyte viability, protein and gene expression were determined in sheets detached from surfaces with or without PGE coating, scaffolds seeded with sheets from PGE-coated plates and the respective monolayers. Stable and vital ligamentocyte sheets could be produced within $24 \mathrm{~h}$ with both surfaces, but more rapidly with PGE coating. PGE did not affect ligamentocyte phenotype. Scaffolds could be colonized with sheets associated with high cell survival, stable gene expression of ligament-related type I collagen, decorin, tenascin C and Mohawk after 14 $\mathrm{d}$ and extracellular matrix (ECM) deposition. PGE coating facilitates ligamentocyte sheet formation, and sheets colonizing the scaffolds displayed a ligament-related phenotype.

Keywords: anterior cruciate ligament; ACL; cell sheet; thermoresponsive polymer; embroidered scaffolds; ligament tissue engineering

\section{Introduction}

Cell sheets represent highly confluent monolayers, associated with their self-made extracellular matrix (ECM). This allows an intimate cell-ECM interaction, which could 
stabilize the tissue-specific phenotype of cells and avoid dedifferentiation, which is often observed in monolayer cultures of primary cells, including tenocytes [1].

Cell sheets for tendon and ligament reconstruction are generally made from various stem cells [2-5] (Table 1). Cell sheets have been used for ligament tissue engineering; however, the production of cell sheets manufactured directly from anterior cruciate ligament (ACL)-derived primary ligamentocytes has barely been reported yet [6]. Cell sheets can be combined with scaffolds $[4,6-8]$ and might allow a directed seeding of distinct scaffold areas with a particular cell type since they can be placed at defined areas of a scaffold [9]. Sheets produced with different or similar cell types can also be stacked $[6,10]$. This is of advantage for tissue engineering of zonal and multiple cell types containing tissues such as periodontal tissue [10] or the attachment part of the ACL to bone representing the so called enthesis. Cell sheet formation and maturation often require many weeks and sheet detachment is time-consuming and associated with the risk of cell layer damage [2].

Thermoresponsive coatings, which can switch by a thermal trigger from a cell-adhesive to a cell-repellent state, could help to gain much faster access to stable cell sheets, e.g., within 17 hours as demonstrated with stem cells [5].

These coatings are usually based on polymers, which undergo a thermally induced reversible phase transition in aqueous solution [11,12], as well as on surfaces at a certain temperature with a concomitant change in polymer chains' hydration and conformation and thus result in reversibly switchable properties of the surface [13]. For cell culture applications the phase transition regime of the thermoresponsive coating on the culture dish needs to be located within the physiologically relevant temperature range below $37^{\circ} \mathrm{C}$. Hence, under standard cell culture conditions the coating is in its dehydrated, collapsed state, which ideally promotes adhesion and proliferation of anchorage-dependent mammalian cells for convenient culture, similar to standard tissue culture polystyrene dishes. Lowering the temperature to ambient temperature (AT), e.g., by simply taking the coated culture dishes out of the incubator, induces the swelling and rehydration of the coating, allowing an enzyme-free release of subconfluent single cells and confluent cell sheets [14,15]. In 1990, the first thermoresponsive coating based on poly( $N$-isopropylacrylamide) (PNIPAm) was developed on standard tissue culture polystyrene for the production of cell sheets $[16,17]$, which is now commercially available under the tradename $\mathrm{UpCell}^{\mathrm{TM}}[18,19]$. These PNIPAm-coated dishes were applied to harvest sheets of different cell types and have already been used for ligament sheet formation by ACL-derived CD34 positive stem cells [5], ACL fibroblasts and rotator cuff-derived cells $[6,20]$ (Table 1). The intimate adaption of cell culture conditions including cell density and supplements are important for successful cell sheet production [14,21] (Table 1).

A novel thermoresponsive and cell-compatible coating was developed on the basis of glycidyl methyl ether (GME) and ethyl glycidyl ether (EGE) by Weinhart et al., representing low molecular weight ( 2-3 kDa) poly(glycidyl ether) (PGE) copolymers with a GME:EGEratio of 1:3 on gold model substrates [22]. Essentially, glycidyl ether-based polymers such as thermoresponsive random PGE copolymers [23] represent a class of polymers with a high number of functional groups in the side chains of the polyether backbone for tailored modification according to the desired application. Hence, they have a high potential for tissue engineering due to low intrinsic toxicity, adjustable water solubility and high chain flexibility [24-26]. After basic structure-property relationship studies with PGEs on gold model substrates [27,28], these functional coatings for cell sheet fabrication were transferred to more commonly applied glass [29] and polystyrene cell culture dishes [14,30], which were used in this study to prepare cell sheets with lapine cruciate ligamentocytes. These ligamentocyte sheets were seeded on a biomechanically competent embroidered scaffold for ligamentogenesis. Since it has not been studied yet, whether the expression profile of ligamentocytes or respective stem/progenitor cells is affected by thermoresponsive surface coatings used for tendon/ligament cell sheet preparation (Table 1) was a particular focus in the present study. 
Hence, key questions in this study are whether PGE allows the formation of sheets of primary cruciate ligamentocytes, whether the coating affects viability and ligamentocyte phenotype. Finally, it should be tested whether ligamentocyte sheets from PGE-coated surfaces can be used to seed embroidered scaffolds and if the ligament-related phenotype is then maintained on these scaffolds.

Table 1. Sheet preparation techniques used for tendon and ligament tissue engineering.

\begin{tabular}{|c|c|c|c|c|c|}
\hline Cell Type & Surface Used & Supplements & Time & Cell Density & Reference \\
\hline LSPC (lapine ACL) & $\begin{array}{c}\text { normal cell culture } \\
\text { surface }\end{array}$ & $\begin{array}{l}50 \mathrm{ng} / \mathrm{mL} \text { of } \\
\text { ascorbic acid }\end{array}$ & $2 \mathrm{w}$ & $6.00 \times 10^{3}$ cells cm $\mathrm{cm}^{-2}$ & [4] \\
\hline $\begin{array}{l}\text { MSCs (cell line) } \\
\text { and TSPCs (human } \\
\text { bone marrow, } \\
\text { Achilles tendon) }\end{array}$ & $\begin{array}{c}\text { normal cell culture } \\
\text { surface }\end{array}$ & $\begin{array}{l}50 \mu \mathrm{g} / \mathrm{mL} \text { ascorbic } \\
\text { acid, high glucose } \\
\text { conditions, } 1 \mathrm{w}\end{array}$ & $\begin{array}{c}\text { until } \\
\text { confluence, } \\
>1 \mathrm{w}\end{array}$ & not provided & [31] \\
\hline $\begin{array}{l}\text { TDSC (human } \\
\text { Achilles tendon) }\end{array}$ & $\begin{array}{c}\text { normal cell culture } \\
\text { surface }\end{array}$ & $\begin{array}{c}50 \mu \mathrm{g} / \mathrm{mL} \text { ascorbic } \\
\text { acid, high glucose } \\
\text { conditions, } 14 \text { or } \\
16.5 \mathrm{~d}\end{array}$ & $\begin{array}{l}\text { until confluence, } \\
>14 \mathrm{w}\end{array}$ & $8.00 \times 10^{3}$ cells cm $^{-2}$ & [32] \\
\hline $\begin{array}{l}\text { TDSC (rat patellar } \\
\text { tendon) }\end{array}$ & $\begin{array}{c}\text { normal cell culture } \\
\text { surface }\end{array}$ & $\begin{array}{c}25 \mu \mathrm{M} \text { ascorbic } \\
\text { acid }(=4.4 \mu \mathrm{g} / \mathrm{mL}), \\
25 \mathrm{ng} / \mathrm{mL} \text { CTGF } \\
25 \mathrm{ng} / \mathrm{mL} \text { CTGF }\end{array}$ & $2 w$ & $5.00 \times 10^{3}$ cells cm $\mathrm{cm}^{-2}$ & [33] \\
\hline $\begin{array}{l}\text { TDSC (rat patellar } \\
\text { tendon) }\end{array}$ & $\begin{array}{c}\text { normal cell culture } \\
\text { surface }\end{array}$ & $\begin{array}{c}25 \mu \mathrm{M} \text { ascorbic } \\
\text { acid } \\
(=4.4 \mu \mathrm{g} / \mathrm{mL})\end{array}$ & $\begin{array}{l}\text { until confluence } \\
\qquad(\sim 2 \mathrm{w})\end{array}$ & $6.00 \times 10^{3}$ cells cm $\mathrm{cm}^{-2}$ & [3] \\
\hline ASC (canine) & $\begin{array}{l}\text { collagen layer in } \\
\text { insert }\end{array}$ & no & $3-4 d$ & $1.00 \times 10^{4}$ cells cm$~^{-2}$ & {$[34]$} \\
\hline ASCs (human) & magnet array plate & $\begin{array}{l}\text { iron oxide chitosan } \\
\text { nanoparticles }\end{array}$ & $7 \mathrm{~d}$ & $6.25 \times 10^{4}$ cells cm $\mathrm{cm}^{-2}$ & [35] \\
\hline $\begin{array}{l}\text { MSCs (sheep, } \\
\text { bone-marrow } \\
\text { derived) }\end{array}$ & $\begin{array}{l}\text { polycaprolactone } \\
\text { (PCL) electrospun } \\
\text { mesh }\end{array}$ & $\begin{array}{c}50 \mu \mathrm{g} / \mathrm{mL} \text { ascorbic } \\
\text { acid }\end{array}$ & $4 \mathrm{w}$ & $5.97 \times 10^{3}$ cells $\mathrm{cm}^{-2}$ & [2] \\
\hline $\begin{array}{l}\text { ACL-derived } \\
\text { CD34+ SCs } \\
\text { (human) }\end{array}$ & $\begin{array}{l}\text { UpCell (CellSeed: } \\
\text { PNIPAm) }\end{array}$ & $\begin{array}{c}\text { BMP2 } \\
\text { overexpression }\end{array}$ & $17 \mathrm{~h}$ & $1.43 \times 10^{5}$ cells cm $\mathrm{cm}^{-2}$ & {$[5,36]$} \\
\hline $\begin{array}{l}\text { ACL fibroblasts } \\
\text { (human) } \\
\text { rotator }\end{array}$ & $\begin{array}{l}\text { UpCell (CellSeed: } \\
\text { PNIPAm) }\end{array}$ & no & not mentioned & $3.00 \times 10^{4}$ cells $\mathrm{cm}^{-2}$ & [6] \\
\hline $\begin{array}{l}\text { cuff-derived cells } \\
\text { (human } \\
\text { supraspinatus } \\
\text { tendon) }\end{array}$ & $\begin{array}{c}\text { UpCell (CellSeed: } \\
\text { PNIPAm) }\end{array}$ & no & $17 \mathrm{~h}$ & $2.63 \times 10^{5}$ cells cm $\mathrm{cm}^{-2}$ & [20] \\
\hline $\begin{array}{l}\text { TDSC (rat AS } \\
\text { tendon) }\end{array}$ & $\begin{array}{c}\text { UpCell (CellSeed: } \\
\text { PNIPAm) }\end{array}$ & $\begin{array}{c}25 \mathrm{mM} \text { ascorbic } \\
\text { acid } \\
(=4.4 \mu \mathrm{g} / \mathrm{mL})\end{array}$ & $3 d$ & $1.56 \times 10^{4}$ cells cm $\mathrm{cm}^{-2}$ & [37] \\
\hline $\begin{array}{l}\text { CL fibroblasts } \\
\text { (lapine) }\end{array}$ & PGE & no & $24 \mathrm{~h}$ & $5-8 \times 10^{5}$ cells $\mathrm{cm}^{-2}$ & present study \\
\hline
\end{tabular}

ACL: anterior cruciate ligament, ASC: adipose tissue derived stem cells, BMP2: bone morphogenetic protein, CL: cruciate ligament, CTGF: connective tissue growth factor, d: day, h: hour, LSPC: ligament stem/progenitor cells, MSC: mesenchymal stromal cells, PCL: polycaprolactone, PGE: poly(glycidyl ether), SCs: stem cells, TDSC: tendon-derived stem cells, TNMD: tenomodulin, TSPCs: tendon specific progenitor cells, w: weeks.

\section{Materials and Methods}

\subsection{Thermoresponsive Surface Coating with PGE on Polystyrene Plates}

Thermoresponsive brushes based on glycidyl methyl ether (GME)/ethyl glycidyl ether (EGE) (1:3) copolymers were self-assembled onto polystyrene 12-well culture plates (Greiner, ThermoFisher Scientific Inc., Darmstadt, Germany) via the physical adsorption of a hydrophobic, photo-reactive benzophenone anchor block based on the monomer 4-[2-(2,3- 
epoxypropoxy)ethoxy]benzophenone (EEBP) as described in detail by Stöbener et al. [15]. Subsequently, the PGE brush layers were covalently immobilized onto the polystyrene surfaces by irradiation with ultraviolet light.

\subsection{Preparation of Embroidered $P(L A-C L) / P L A$ Scaffolds}

Embroidered scaffolds ( $15 \mathrm{~mm} \times 4 \mathrm{~mm} \times 1 \mathrm{~mm}$ ) were prepared using two different thread materials. The first one was a monofilament thread consisting of P(LA-CL), which was commercially produced (USP 7-0, Gunze Ldt., Osaka, Japan). The second material was a PLA multifilament (six filaments, $\mathrm{Tt}=155 \mathrm{dtex}$, based on Ingeo biopolymer 6202D, (NatureWorks, Minnetonka, MN, USA)), which was melt spun at the Leibniz-Institut für Polymerforschung Dresden e. V. (IPF) in Dresden (Germany). Scaffolds were embroidered using an embroidery machine (JCZ 0209-550, ZSK Stickmaschinen GmbH, Krefeld, Germany). P(LA-CL) served as upper and PLA as lower thread in each ply for scaffold production on a water-soluble non-woven sheet of polyvinyl alcohol (PVA, Freudenberg Einlagestoffe KG, Weinheim, Germany). A zig-zag pattern design with $1.8 \mathrm{~mm}$ stitch length, $15^{\circ}$ stitch angle and $0.2 \mathrm{~mm}$ duplication shift was used for embroidering. Three plies were stacked and locked together to design a three-dimensional (3D) scaffold. The PVA was washed out three times for $30 \mathrm{~min}$ in tap water on a compact shaker (KS 15 A, Edmund Bühler GmbH, Bodelshausen, Germany). The 3D scaffolds were dried at AT.

\section{Functionalization of Embroidered P(LA-CL)/PLA Scaffolds}

Embroidered scaffolds were fluorinated for $60 \mathrm{~s}$ in a fluorination batch reactor (FluorTechnik-System GmbH, Lauterbach, Germany) at FILK (FILK Freiberg Institute gGmbH, Germany) using a mixture of $10 \%$ fluorine gas in air. After fluorination, scaffolds were flushed with synthetic air and then functionalized with purified native bovine type I collagen forming a refibrillated hydrogel, which is then lyophilized on the polymer threads of the embroidered polymer prepared at FILK. For stabilization the collagen was crosslinked with the gas phase of hexamethylene diisocyanate (HMDI, Merck KGaA, Darmstadt, Germany) in an exsiccator [38]. Scaffolds were sterilized by incubation in 70\% ethanol $(\mathrm{ETOH})$ for $30 \mathrm{~min}$ followed by rinsing three times in distilled water before incubation in fetal bovine serum (FBS, Bio\&SELL, GmbH, Feucht, Germany) until seeding.

\subsection{Isolation of Lapine Cruciate Ligamentocytes}

Lapine cruciate ligaments used for cell isolation were obtained from the abattoir. Lapine cruciate ligamentocytes were isolated from four healthy female and one male New Zealand Rabbits (mean age of 12 months). Surrounding connective tissue was removed and 1-2-mm sized pieces of the cruciate ligaments were prepared and transferred into a T-25 culture flask (Sarstedt AG \& Co. KG, Nürnbrecht, Germany) with $2 \mathrm{~mL}$ culture medium (Dulbecco's Modified Eagle's Medium (DMEM)/Ham's F12 medium [1:1] (Bio\&SELL), containing $10 \%$ fetal bovine serum (FBS, Bio\&SELL), $1 \%$ penicillin/streptomycin solution, $25 \mu \mathrm{g} / \mathrm{mL}$ ascorbic acid (Sigma-Aldrich, Munich, Germany), $2.5 \mu \mathrm{g} / \mathrm{mL}$ amphotericin B (Bio\&SELL) and MEM amino acid solution (Sigma-Aldrich)). Culture medium was changed every 2-3 days. After around 1 week, cruciate ligamentocytes emigrated from the explant. Cells were detached after being $80 \%$ confluent using $0.05 \%$ trypsin $/ 0.02 \%$ ethylenediaminetetraacetic acid (EDTA) solution (Bio\&SELL). Cell numbers and viability were calculated with a hemocytometer using the trypan blue exclusion assay.

\subsection{Preparation of Ligamentocyte Sheets and Scaffold Seeding with Sheets}

A total of 5-8 $\times 10^{5}$ ligamentocytes per $\mathrm{cm}^{2}$ from 3-5 different donors were seeded on a 12-well polystyrene cell culture plate coated with PGE for $24 \mathrm{~h}$. As controls served cells, which were seeded into cell culture plates without PGE coating at identical cell density and cells cultured as monolayers $\left(2.4 \times 10^{3}\right.$ per $\left.\mathrm{cm}^{2}\right)$ in a density normally used for cell expansion. After detachment with phosphate buffered saline (PBS, Bio\&SELL) with $\mathrm{Ca}^{++}$ and $\mathrm{Mg}^{++}$using a temperature shift between $\mathrm{AT}\left(21^{\circ} \mathrm{C}, 10 \mathrm{~min}\right)$ and $37^{\circ} \mathrm{C}(5 \mathrm{~min})$, the 
cell sheets were cultivated for $7 \mathrm{~d}$ in a 24-well ultra-low attachment plate (CORNING, Tewksbury, MA, USA). Cell sheets from control plates were detached in a similar manner. If no sheet detachment was observed at $37^{\circ} \mathrm{C}$ in the incubator, the plate was transferred to AT conditions again until sheet release was achieved. Sheet detachment was supported by pipetting PBS under the margins of the sheets in the well.

Since it was much less time-consuming to harvest intact ligamentocyte sheets from the PGE-coated surface, and cell sheet detachment from uncoated surfaces occasionally resulted in disrupted cell sheets, only sheets harvested from PGE plates were used for scaffold seeding. Two ligamentocyte sheets were carefully wrapped around one half (length: $7.5 \mathrm{~mm}$ ) of an embroidered P(LA-CL)/PLA scaffold functionalized through gasphase fluorination and cross-linked collagen foam. The scaffold was placed onto the cell sheet during sheet detachment and a second sheet was transferred with a pipette onto the surface of the scaffold. Scaffolds were cultured for 7 and $14 \mathrm{~d}$.

\subsection{Viability Assay of Cruciate Ligamentocytes in Sheets, Monolayers and Scaffolds Colonized with Sheets}

Viability of ligamentocyte sheets, monolayer and scaffolds (one half of a longitudinally transected scaffold) colonized with sheets was assessed using a live/dead assay staining with fluorescein diacetate (FDA, Sigma-Aldrich) and propidium iodide (PI, Carl Roth $\mathrm{GmbH}$ and Ko.KG, Karlsruhe, Germany). Ligamentocytes were incubated for at least $30 \mathrm{~s}$ in the staining solution before starting microscopical examination. The solution consisted of $0.5 \%$ FDA and $0.1 \%$ PI dissolved in PBS. The green (living cells, cytoplasm of cells stained with FDA) or red (cell nuclei of dead cells stained with PI) fluorescence was monitored using a SPEII confocal laser scanning microscope (CLSM, Leica Microsystems GmbH, Wetzlar, Germany). The colonized area was measured based on the living cells with the ImageJ program. The cell viability was assessed based on the ratio of the area of the living cells compared to the area of the dead cells with the Image J program.

\subsection{Histological Staining of Cell Sheets}

The cell sheets were fixed for 15 min with $4 \%$ paraformaldehyde (PFA) and placed inside HistoGel (ThermoFisher Scientific Inc., Germany) before being embedded in paraffin. Sections of $7 \mu \mathrm{m}$ were prepared. The sections were $10 \mathrm{~min}$ deparaffinized in xylol (Carl Roth $\mathrm{GmbH}$ and Ko.KG) and rehydrated with a descending ethanol row (ETOH, 99.8\%, 96\%, 80\%, 70\%) (Carl Roth GmbH and Ko.KG).

For hematoxylin-eosin (HE) staining, sections of sheets were incubated for $6 \mathrm{~min}$ in Harry's hematoxylin (Carl Roth GmbH and Ko.KG), before being rinsed in running tap water and counterstained for $4 \mathrm{~min}$ in eosin (Carl Roth $\mathrm{GmbH}$ and Ko.KG).

For the alcian blue $(\mathrm{AB})$ stain, sections were incubated for $3 \mathrm{~min}$ in $1 \%$ acetic acid. Then they were incubated for $30 \mathrm{~min}$ in $1 \% \mathrm{AB}$ staining solution (Carl Roth $\mathrm{GmbH}$ and Ko.KG). After rinsing in 3\% acetic acid and followed by a washing step in distilled water lasting $2 \mathrm{~min}$, cell nuclei were counterstained with nuclear fast red aluminum sulphate solution (Carl Roth GmbH and Ko.KG) for 5 min. HE- and AB-stained sections were covered with Entellan (Merck KGaA). Images were taken using a light microscope (DM1000 LED, Leica Microsystems GmbH).

\subsection{RNA Isolation from Ligamentocyte Monolayers, Sheets and Scaffolds Colonized with Sheets}

Ligamentocyte sheets and halves of a scaffolds $(7.5 \mathrm{~mm})$ colonized with ligamentocyte sheets were gently rinsed in PBS before being snap-frozen and stored at $-80{ }^{\circ} \mathrm{C}$ until dissected in 1-mm-sized pieces and incubated for $15 \mathrm{~min}$ in RLT buffer (Qiagen $\mathrm{GmbH}$, Hilden, Germany) supplemented with 1\% mercaptoethanol. Samples were homogenized with the tissue lyser two times for 3 minutes at $50 \mathrm{~Hz}$. RNA was isolated using the RNeasy Mini kit according to the manufacturer's recommendation (Qiagen $\mathrm{GmbH}$ ) including an oncolumn DNA removal. Quantity and purity of the RNA was analyzed using the Nanodrop ND-1000 spectrophotometer (Peqlab, Biotechnologie GmbH, Erlangen, Germany) at the $260 / 280$ absorbance ratio. 


\subsection{Quantitative Real-Time PCR}

Total RNA was reversely transcribed into cDNA using the QuantiTect Reverse Transcription Kit (Qiagen $\mathrm{GmbH}$ ) according to the manufacturer's instructions. For each quantitative real-time PCR (qRT-PCR) the TaqMan Gene Expression Assay (Life Technologies) was used. Specific primer pairs for type I collagen (COL1A1), decorin (DCN), tenascin (TNC), Mohawk (MKX) and the reference gene glycerin-aldehyde-3-phosphatedehydrogenase (GAPDH) were used (Table 2). qRT-PCR was performed using the real-time PCR detector StepOnePlus (Applied Biosystems (ABI), Foster City, CA, USA) thermocycler with StepOnePlus software 2.3 (ABI). Mean normalized expressions of the genes of interest in the sheets were determined in relation to the reference gene GAPDH and calculated for each specimen [39].

Table 2. Primers used to assess gene expression.

\begin{tabular}{|c|c|c|c|c|c|c|}
\hline Gene Symbol & Species & Gene Name & NCBI Gene Reference & Efficacy & $\begin{array}{c}\text { Amplicon } \\
\text { Length (bp) }\end{array}$ & Assay ID * \\
\hline COL1A1 & O. cuniculus & type I collagen & AY633663.1 & 1.94 & 70 & Oc03396073_g1 \\
\hline $\mathrm{DCN}$ & $\begin{array}{c}\text { Homo } \\
\text { sapiens }\end{array}$ & decorin & NM_133503.3 & 2.03 & 77 & Hs00370384_m1 \\
\hline GAPDH & O.cuniculus & $\begin{array}{l}\text { glycerin- } \\
\text { aldehyde-3- } \\
\text { phosphate- } \\
\text { dehydro- } \\
\text { genase }\end{array}$ & NM_001082253.1 & 1.95 & 82 & Oc03823402_g1 \\
\hline MKX & O.cuniculus & Mohawk & XM_002717295.1 & 1.83 & 60 & Oc06754037_m1 \\
\hline TNC & O. cuniculus & tenascin $C$ & FJ480400.1 & 1.83 & 61 & Oc06726696_m1 \\
\hline
\end{tabular}

O.: Oryctolagus * All primers from Applied Biosystems ${ }^{\circledR}$ (life technologies ${ }^{\mathrm{TM}}$ ).

2.9. Immunofluorescence Analysis of Ligament ECM Protein Expression in Ligamentocyte Sheets and Scaffolds Colonized with Sheets

The protein expression of ligament-related components within cell sheets was detected by immunolabeling sheets and scaffolds. Immunoreactivity was detected using the CLSM. Ligamentocyte sheets or scaffolds colonized with cell sheets were fixed for $15 \mathrm{~min}$ in $4 \%$ PFA, before being rinsed in TRIS buffered saline (TBS: $0.05 \mathrm{M}$ TRIS, $0.015 \mathrm{M} \mathrm{NaCl}, \mathrm{pH}$ 7.6), and then, incubated with protease-free blocking solution (5\% donkey serum diluted in TBS with $0.1 \%$ Triton $\times 100$ for cell permeabilization) for $20 \mathrm{~min}$ at AT. Subsequently, cell sheets and scaffolds were incubated with primary antibodies suspended in blocking solution (type I collagen (1:30, goat-anti-human), decorin (1:50, rabbit-anti-human) and $\alpha$-smooth muscle actin ( $\alpha$ SMA, 1:50, mouse-anti-human) (Table 3 ) overnight at $4{ }^{\circ} \mathrm{C}$ in a humid chamber. Negative controls were treated in a similar manner except for omitting the primary antibodies. Sheets and scaffolds were rinsed three times with TBS before incubation with secondary antibodies (cyanine[cy]3 labeled donkey-anti-mouse or -antigoat as well as donkey-anti-rabbit coupled with Alexa-Fluor488) diluted 1:200 in TBS overnight at $4{ }^{\circ} \mathrm{C}$ in a humid chamber. Cell nuclei were visualized using $10 \mu \mathrm{g} / \mathrm{mL} 4^{\prime}, 6^{\prime}$ diamidino-2-phenylindol (DAPI, Roche, Mannheim, Germany). In addition, some sheets were stained with phalloidin Alexa-Fluor488 (Table 3) and DAPI diluted in blocking buffer to visualize F-actin and cell nuclei. Immunolabeled or F-actin-stained cell sheets and scaffolds were rinsed three times for $5 \mathrm{~min}$ with TBS. Photos were immediately taken after staining using a CLSM (100 $\mu \mathrm{m}$ stack with 63 images each). 
Table 3. Antibodies and staining used to assess protein expression in cell sheets.

\begin{tabular}{|c|c|c|c|c|}
\hline Target & Primary Antibody & Dilution & $\begin{array}{l}\text { Secondary } \\
\text { Antibody }\end{array}$ & Dilution \\
\hline collagen type I & $\begin{array}{c}\text { goat-anti-human } \\
\text { (COL1A1 chain), } \\
\text { Abcam, Cambridge, } \\
\text { UK }\end{array}$ & $1: 50$ & $\begin{array}{l}\text { donkey-anti-goat; cy } \\
\text { 3, Dianova GmbH, } \\
\text { Hamburg, Germany }\end{array}$ & $1: 200$ \\
\hline decorin & $\begin{array}{c}\text { rabbit-anti-human, } \\
\text { OriGene Rockville, } \\
\text { MD, USA }\end{array}$ & $1: 50$ & $\begin{array}{c}\text { donkey-anti-rabbit; } \\
\text { Alexa-Fluor488, } \\
\text { ThermoFisher } \\
\text { Scientific Inc., } \\
\text { Germany }\end{array}$ & $1: 200$ \\
\hline $\begin{array}{l}\text { phalloidin Alexa- } \\
\text { Fluor } 488\end{array}$ & $\begin{array}{l}\text { stains filamentous } \\
\text { (F-) actin, Santa } \\
\text { Cruz Biotechnology, } \\
\text { Inc, Dallas, TX, USA }\end{array}$ & $1: 200$ & - & - \\
\hline $\begin{array}{l}\alpha \text {-smooth } \\
\text { muscle actin }\end{array}$ & $\begin{array}{l}\text { mouse-anti-human, } \\
\text { Sigma-Aldrich } \\
\text { (A5228), Munich, } \\
\text { Germany }\end{array}$ & $1: 50$ & $\begin{array}{l}\text { donkey-anti-mouse; } \\
\text { cy3, Dianova GmbH, } \\
\text { Hamburg, Germany }\end{array}$ & $1: 200$ \\
\hline
\end{tabular}

\subsection{Statistical Analysis}

Data was expressed as mean values with standard deviation. Statistics were performed using Graphpad Prism 8 (version 8.4.3, GraphPad Software Inc., San Diego, USA). Normalized and unnormalized data were evaluated using one-way ANOVA and/or one sample t-test, two-tailed. Statistical significance was set at a $p$ value of $\leq 0.05$. The Grubbs test was applied to identify outliers, which were excluded.

\section{Results}

\subsection{Ligamentocyte Sheets from PGE-Coated Plates Detach More Rapidly Than Those Harvested from Uncoated Plates}

Conditions for cell sheet formation such as required cell numbers depend on cell type [15]. A total of 5-8 $\times 10^{5}$ cruciate ligamentocytes per $\mathrm{cm}^{2}$ were at least required to allow stable cell sheet formation. After $24 \mathrm{~h}$ cell attachment and growth phase, the ligamentocytes at the margin of the 12-well started to detach spontaneously; thereby, a cell-free border developed (Figure 1A). The interspace between the wall of the 12-well and the cell layer was measured. This distance was significantly larger in cell culture plates with PGE coating $(152.4 \pm 47.7 \mu \mathrm{m})$ compared to the uncoated plates $(99.5 \pm 56.1 \mu \mathrm{m})$ after $24 \mathrm{~h}$ (Figure 1B1). Hence, there were also occasional difficulties in releasing an intact ligamentocyte sheet from the uncoated plates. The sheets harvested from the uncoated plates were more fragile, sometimes having tears or being tattered.

Nevertheless, intact ligamentocyte sheets could be produced within $24 \mathrm{~h}$ with both cell culture plates with and without PGE coating, but the time needed for cell detachment from the PGE-coated plate $(4.9 \pm 8.1 \mathrm{~min})$ compared to that required when using an uncoated plate $(21.7 \pm 22.7 \mathrm{~min})$ was significantly lower (Figure 1B2). 

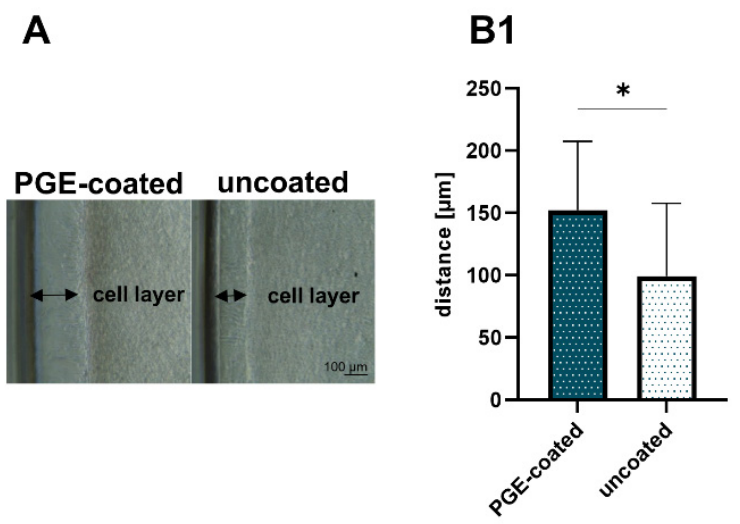

B2

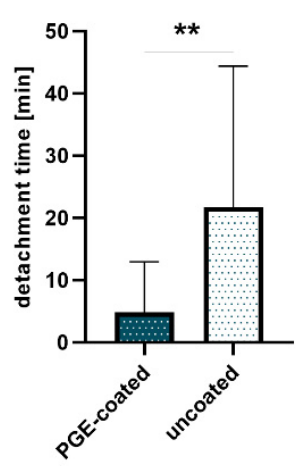

Figure 1. Self-detachment before thermal treatment and detachment time after treatment. (A) Cellfree border in poly(glycidyl ether) (PGE)-coated and uncoated control plates. (B1) Distance between well wall and margin of the ligamentocyte layer measured in PGE-coated and uncoated plates, $\mathrm{n}=3$ independent experiments with ligamentocytes of different donors. (B2) Detachment time in PGE-coated and uncoated plates, $\mathrm{n}=4$ independent experiments with ligamentocytes of four different donors. Scale bar: $100 \mu \mathrm{m}$ (A). Statistic: One sample t-test, two-tailed $\left({ }^{*}\right) . p$ values: ${ }^{*}<0.05$, ** $<0.01$ (B1,B2).

\subsection{Viability of Ligamentocytes Is Maintained in Cell Sheets}

The relative viability of the sheets did not decrease significantly after detachment (day 0 ) and $7 \mathrm{~d}$ of culturing. There was no significant difference in viability in the sheets compared to the respective monolayer. In addition, it was shown that PGE coating did not change the cell viability of sheets in comparison to the uncoated 12-well plates (Figure 2A1-D).
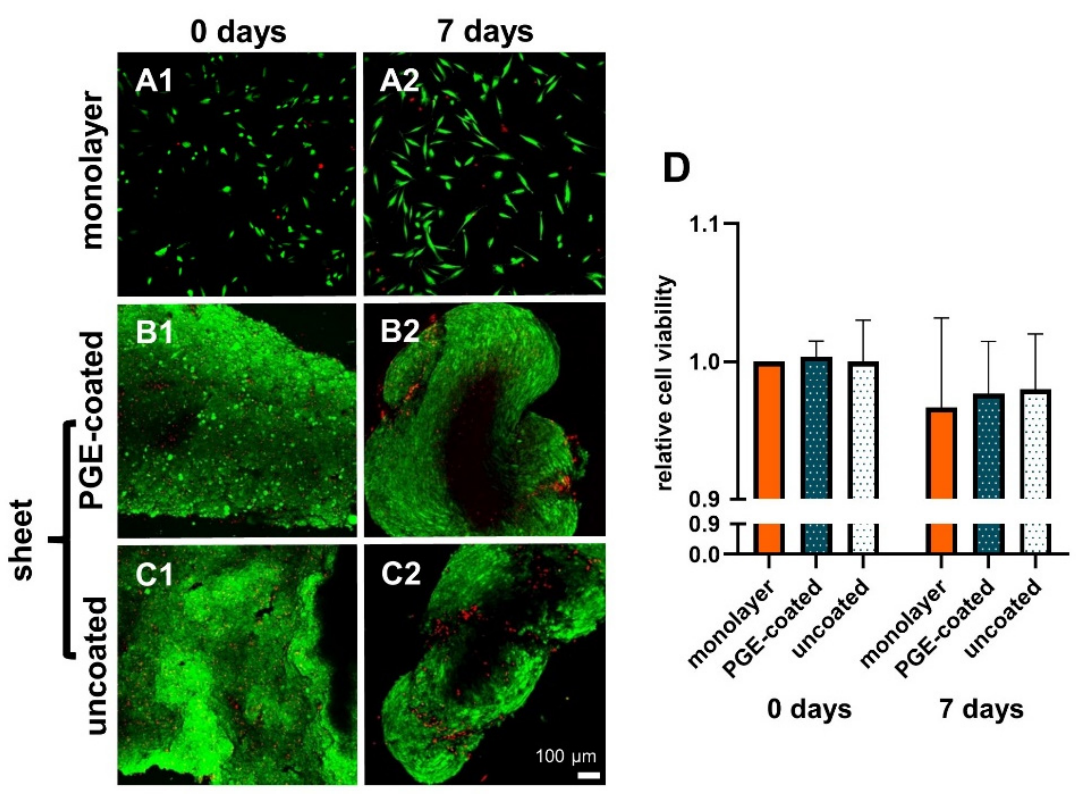

Figure 2. Viability of ligamentocytes in monolayer used for sheet preparation and respective sheets prepared on PGE-coated and uncoated plates and cultured for $7 \mathrm{~d}$ in non-adherent culture dishes. $0 \mathrm{~d}$ (A1,B1,C1), $7 \mathrm{~d}$ (A2,B2,C2), monolayer of the same cell donor (A1,A2). Poly(glycidyl ether) (PGE)-coated plates (B1,B2), uncoated plates (C1,C2). Green: vital, red: dead cells (A1-C2). (D) Measurements of relative cell viability in monolayer, PGE-coated and uncoated plates after 0 and 7 $\mathrm{d}, \mathrm{n}=3$ independent experiments with ligamentocytes of three different donors. Scale bar: $100 \mu \mathrm{m}$ (A1-C2). Statistic: One sample t-test, two-tailed (comparison with day 0 monolayer), paired one-way ANOVA (comparison between the groups) (D). 


\subsection{Histological Examination of Cell Sheets Reveals Homogenous Cell Distribution and Sulphated Glycosaminoglycan Deposition}

The ligamentocyte sheets harvested from both types of plates were investigated using HE staining to gain an overview of tissue structure. AB staining was performed to estimate sulphated glycosaminoglycan (sGAG) deposition. Observation at the timepoint immediately after detachment (day 0 ) revealed a high cell density with many densely packed cell nuclei and some ECM. Detached ligamentocyte sheets showed a random and dense cell arrangement with no differences between sheets from uncoated and coated surfaces (Figure 3A1-D1). However, after $7 \mathrm{~d}$ the cell nuclei in inner regions of the sheets were localized with a larger distance between each other and a larger amount of ECM became visible between the cells (Figure 3A1-D1 vs. Figure 3A2-D2). HE-stained crosssections of isolated ligamentocyte sheets showed that the detached sheets were already more than 4 cell diameters thick. At $7 \mathrm{~d}$ the folds of the sheets had more or less fused, forming a 3D construct, still with irregular cell arrangement. This was different from the cell arrangement in rows normally detectable in the native ACL of the rabbit by HE and $\mathrm{AB}$ staining (Figure 3B3-D3). AB staining of the ligamentocyte sheets revealed a faint blue staining in the ECM between cells, which proved sGAG deposition already at day 0 but also later at day 7 (Figure 3C1,D1,C2,D2). sGAG deposition in sheets produced on PGE-coated and uncoated surfaces was generally weak resembling the faint staining observed in the native ACLs (Figure 3C2,D2,D3).

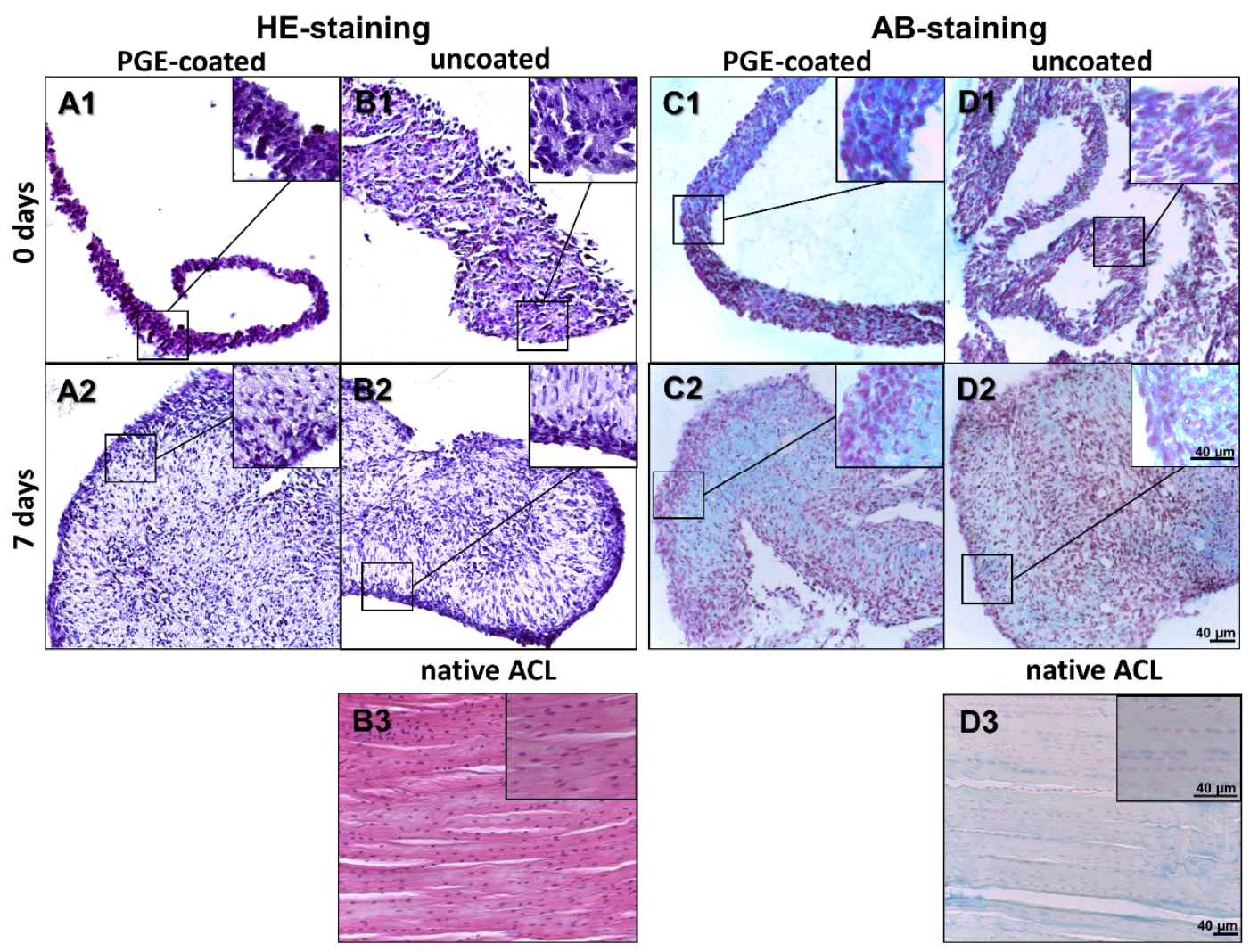

Figure 3. Histology of lapine ligamentocyte sheets $(0 \mathrm{~d})$ released from PGE-coated and uncoated plates and after culturing for 7 days. Paraffin sections of sheets released from surfaces coated with poly(glycidyl ether) (PGE) or uncoated plates stained with hematoxylin-eosin (HE, A1, B1,A2,B2) or alcian blue (AB, C1,D1,C2,D2). 0 d (A1,B1,C1,D1), 7 d (A2,B2,C2,D2). Native lapine anterior cruciate ligament (HE: B3, AB: D3), scale bars: $40 \mu \mathrm{m}$. 


\subsection{Surface Area of Sheets Decreases after Detachment and during Culturing}

After detachment, the surface of the ligamentocyte sheets was significantly smaller (61.6 $\pm 4.3 \mathrm{~mm}^{2}$ with PGE coating vs. $66.1 \pm 9.0 \mathrm{~mm}^{2}$ without coating) than the original growth area of the 12-well plates (manufacturer information for the surface of the 12 wells: $365 \mathrm{~mm}^{2}$ with PGE coating and $390 \mathrm{~mm}^{2}$ without coating) and it significantly further decreased ( $3.1 \pm 0.8 \mathrm{~mm}^{2}$ with PGE coating vs. $3.6 \pm 0.5 \mathrm{~mm}^{2}$ without coating) during the following 7-d cultivation period. At the end of the observation period the cell sheets formed a 3D construct (Figure 4A,B). F-actin stress fibers and $\alpha$ SMA were visualized in the monolayer and ligamentocyte sheets freshly released from the PGE-coated and uncoated plates (Figure 4C1-C3). The structure of the actin cytoskeleton was depicted to try to explain the shrinkage after sheet detachment. The expression of F-actin and $\alpha$ SMA did not show major differences in the sheets harvested from the PGE-coated and uncoated plates. F-actin revealed a net-like overall structure in the sheets consisting of densely packed cells (Figure 4C2,C3).
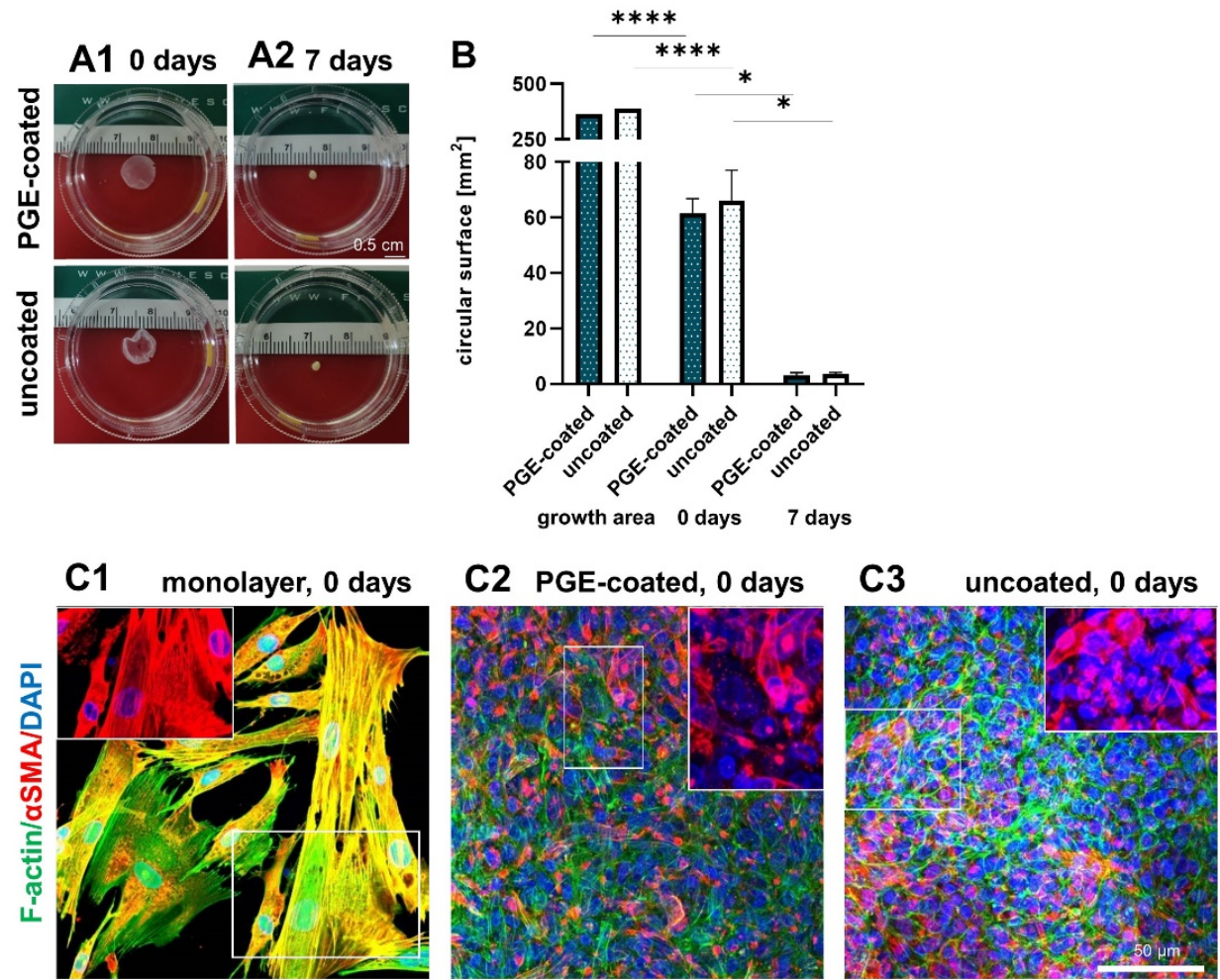

Figure 4. Shape and size of the sheets after detachment $(0 \mathrm{~d})$ and when cultured for $7 \mathrm{~d}$. Shape of ligamentocyte sheets after $0 \mathrm{~d}$ (A1) and $7 \mathrm{~d}$ (A2) transferred to a Petri dish. (B) Circular surface of sheets released from poly(glycidyl ether) (PGE)-coated and uncoated plates after 0 and $7 \mathrm{~d}$ in comparison to the growth area of one well of the respective 12-well plate. $n=3$ independent experiments with ligamentocytes of three different donors. (C) F-actin (green) and $\alpha \mathrm{SMA}$ (red) of the monolayer (C1) and sheets released from PGE-coated (C2) and uncoated (C3) plates. The insets show exclusively $\alpha$ SMA at higher magnification (red). Cell nuclei were counterstained using 4',6-diamidino-2-phenylindole (DAPI, blue). Scale bars: $0.5 \mathrm{~cm}$ (A1-A3), $50 \mu \mathrm{m}$ (C). (B) Statistic: unpaired one-way ANOVA (comparison between the groups) $\left({ }^{*}\right) . p$ values: ${ }^{*}<0.05$, $* * * *<0.0001$.

The ligamentocytes in the monolayer culture often displayed stress fibers, which were oriented mainly parallel to the longitudinal cell axis leading to cell-cell and cell-substrate contacts. $\alpha$ SMA was generally expressed by a subpopulation of cells. In the monolayer, it was expressed by most of the cells and was more evenly distributed over their entire cytoplasm, often co-localizing with the F-actin fibers (Figure 4C1). In contrast, $\alpha \mathrm{SMA}$ was focally expressed in the ligamentocyte sheets, often only in the perinuclear $\mathrm{rER}$ region and only few cells showed a distribution over the entire cytoplasm (Figure 4C2,C3). 


\subsection{Ligament-Related Genes Are Expressed in Isolated Cell Sheets Released from Surfaces} with or without PGE Coating

At both observation time points (day 0, immediately after ligamentocyte sheet detachment) and day 7 the gene expression for COL1A1, DCN, TNC and MKX did not significantly differ between sheets released from PGE-coated or uncoated surfaces (Figure $5 \mathrm{~A}-\mathrm{D})$. After $7 \mathrm{~d}$ of culturing, COL1A1 and DCN gene transcription was significantly lower in both types of cell sheets compared to the monolayer of day 0 , and the COL1A1 mRNA level of the sheet derived from the uncoated plate was also significantly lower compared to the 7-day-old monolayer (Figure 5A,B). However, TNC expression was significantly higher in the monolayer (day 0) compared to both types of sheets at the same time point (day 0) (Figure 5C). Compared to the monolayer, TNC gene expression was only lower in the 7-day-old cell sheets released from the uncoated plates. Gene expression of MKX increased (day 7, not significant) in those from the PGE-coated plates compared to the monolayers of day 0 (Figure 5C,D). Nevertheless, at day 7 the expression of TNC and MKX did not significantly differ between sheets and monolayer of the same time point (Figure 5C-D).
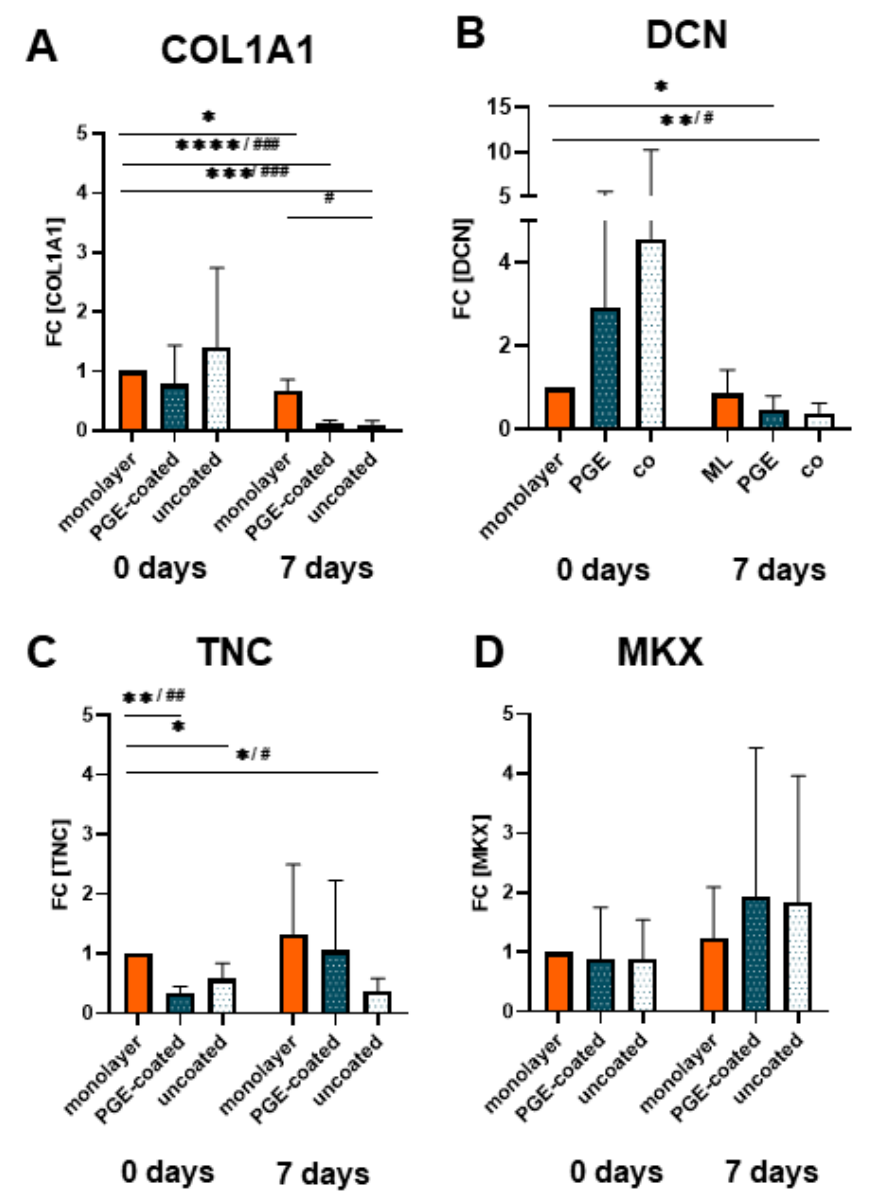

Figure 5. Gene expression of ligamentocytes cultured in the monolayer or as cell sheets after detachment $(0 \mathrm{~d})$ and when cultured for $7 \mathrm{~d}$. (A) Type I collagen (COLA1, type I collagen A1 chain), (B) decorin (DCN), (C) Tenascin C (TNC) and (D) Mohawk (MKX) expression in monolayer, poly(glycidyl ether) (PGE)-coated and uncoated plates after 0 and $7 \mathrm{~d}, \mathrm{n}=4$ independent experiments with ligamentocytes of four different donors. Statistic: One sample t-test, two-tailed (comparison with day 0 monolayer) $\left(^{*}\right)$, paired one-way ANOVA (comparison between the groups) (\#), Grubbs test $(\alpha=0.05)$. $p$ values: ${ }^{*} / \#<0.05,{ }^{* *} / \# \#<0.01,{ }^{* * *} / \# \# \#<0.001,{ }^{* * * *} / \# \# \#+0.0001$ (A-D). 


\subsection{Scaffolds Can Be Colonized with Ligamentocyte Sheets Harvested from PGE-Coated Surfaces}

Cruciate ligamentocyte cell sheets adhered to embroidered scaffolds and cells spread onto the scaffold (Figure 6A). There was no decrease in viability of cells colonizing the scaffolds. When the viability of cells in the monolayer, cells on the scaffold and those in harvested and cultured cell sheets from PGE-coated plates were compared between 0, 7 and $14 \mathrm{~d}$ no significant difference could be detected (Figure 6B). The scaffold area covered with living cells increased significantly from $7(2.7 \pm 3.1 \%)$ to $14 \mathrm{~d}(11.6 \pm 5.8 \%)$ (Figure $6 \mathrm{C})$.
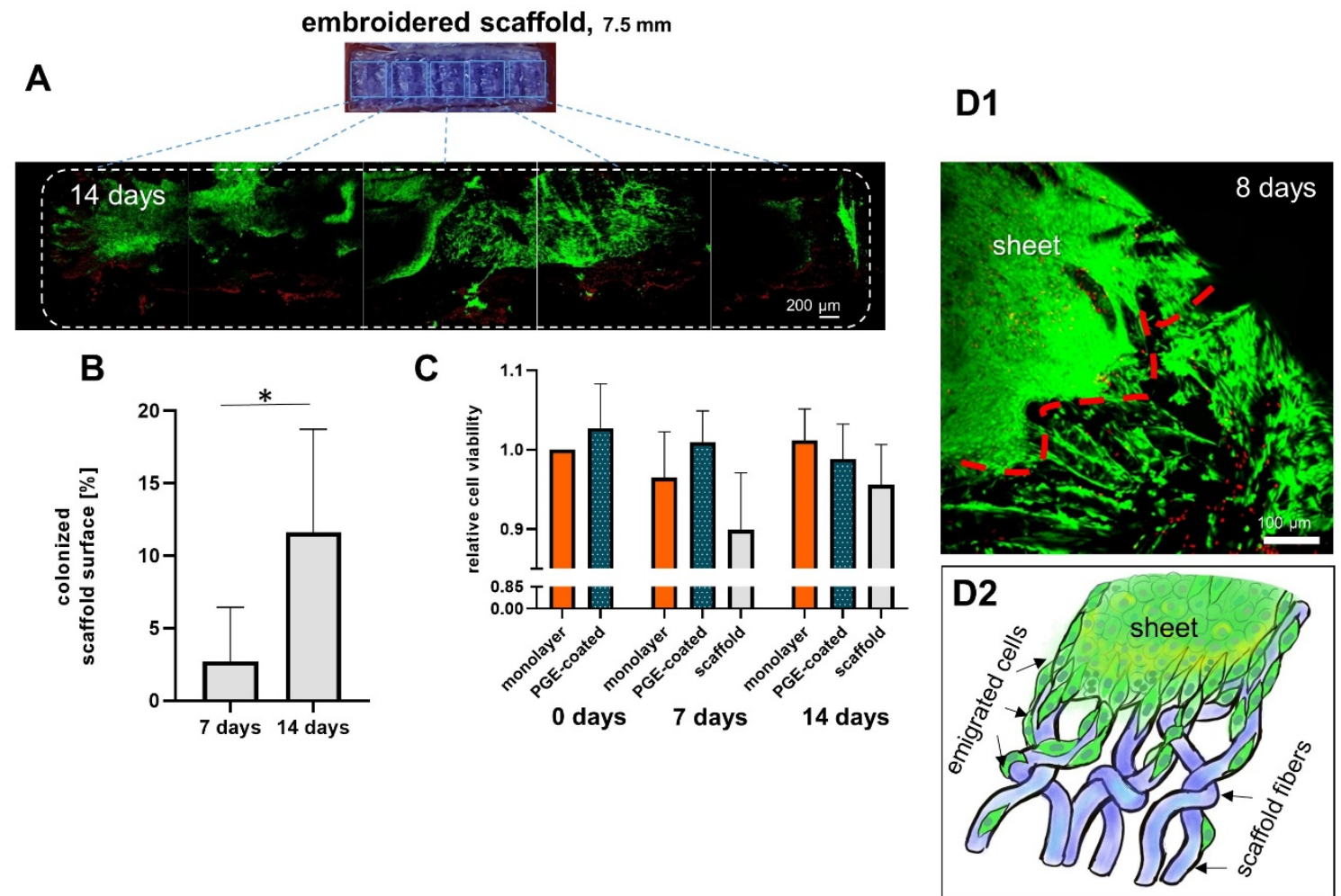

Figure 6. Ligamentocyte viability and colonized scaffold surface area of ligamentocytes emigrated from ligamentocyte sheets on a P(LA-CL)/PLA scaffold prepared with PGE-coated dishes after 7 and $14 \mathrm{~d}$. (A) Colonization of the scaffold by ligamentocytes is shown ( $14 \mathrm{~d}$, a half of the scaffold is shown). Green: vital, red: dead cells. B) Colonized scaffold surface after 7 and $14 \mathrm{~d}$. Comparison of cell viability in monolayer, isolated cell sheets released from poly(glycidyl ether) (PGE)-coated plates and colonized scaffolds, $\mathrm{n}=3$ independent experiments with ligamentocytes of three different donors. (C) Relative ligamentocyte viability, $\mathrm{n}=4$ independent experiments with ligamentocytes of four different donors. ((D1) Cells emigrating from a cell sheet onto P(LA-CL)/PLA scaffolds after 8 days at higher magnification (red line $=$ border of the sheet) and (D2) a scheme of cell emigration from a sheet on scaffold fibers. (A) Scale bar: $200 \mu \mathrm{m}$. Statistic: (B) One sample t-test, two-tailed (comparison with day 0 monolayer), paired one-way ANOVA (comparison between the groups). (C) One sample t-test, two-tailed $\left({ }^{*}\right), p$ values: ${ }^{*}<0.05$.

\subsection{Ligament-Related Genes Are Expressed in Ligamentocyte Sheets and Scaffolds Seeded with Them}

Relative gene expression of COL1A1 decreased significantly in cell sheets (manufactured on surfaces with PGE coating) and cultured for 7 and $14 \mathrm{~d}$ compared to the monolayer at $0 \mathrm{~d}$ (Figure 7A). However, the relative gene expression of COL1A1, DCN, TNC and MKX tended to be upregulated in scaffolds colonized by cell sheets in comparison to cell sheets alone (Figure 7A-D) and that of COL1A1, DCN and TNC was also higher in comparison to the monolayer at day 14 (Figure $7 \mathrm{~A}-\mathrm{C}$ ). 

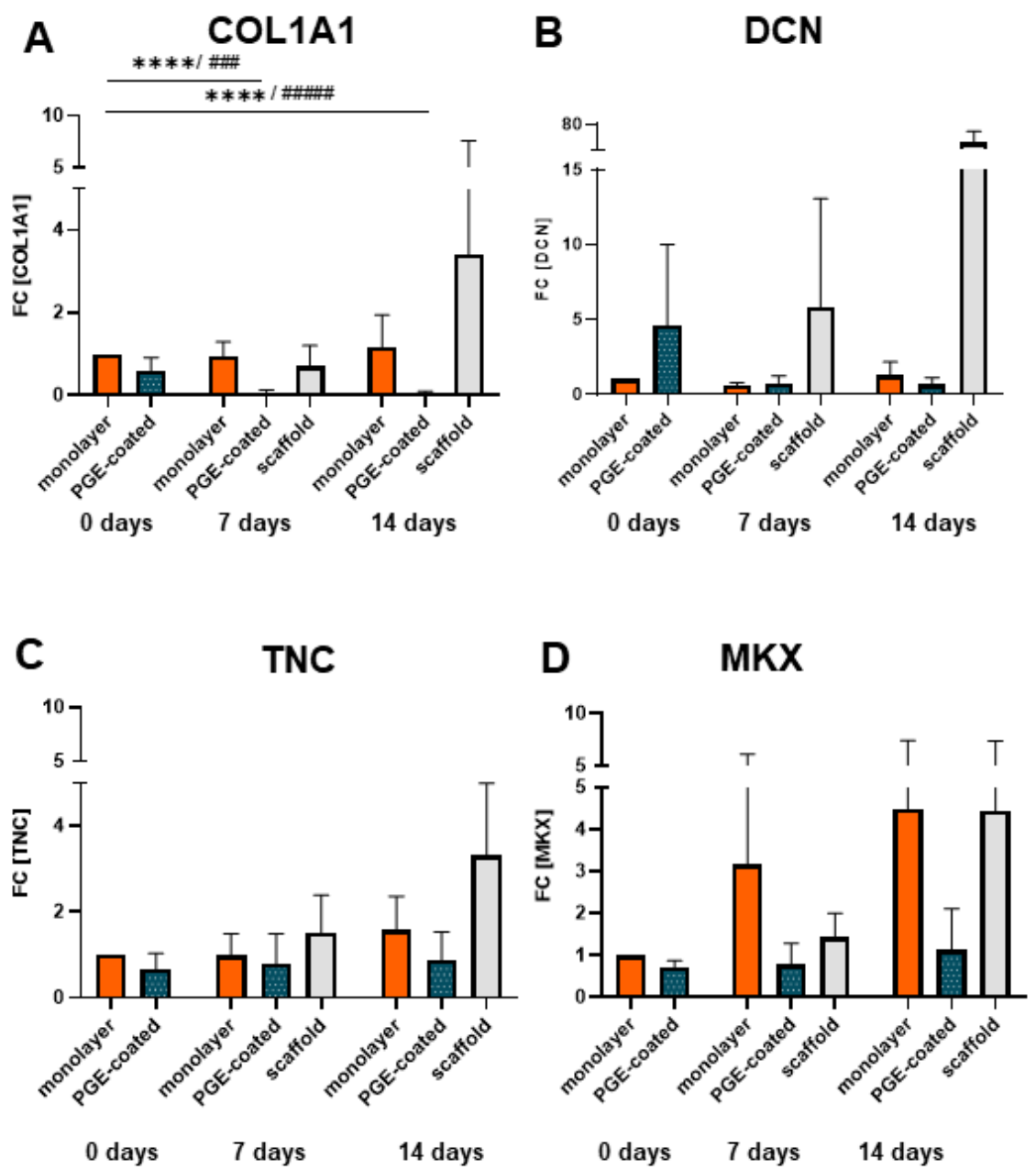

Figure 7. Gene expression of ligamentocytes cultured in monolayers, in sheets harvested from PGEcoated plates or in the scaffolds seeded using sheets after detachment $(0 \mathrm{~d}), 7$ and $14 \mathrm{~d}$. (A) Type I collagen (COLA1), (B) decorin (DCN), (C) Tenascin C (TNC) and (D) Mohawk (MKX) gene expression in monolayer, poly(glycidyl ether) (PGE)-coated and uncoated plates after 0,7 and $14 \mathrm{~d}, \mathrm{n}=4$ independent experiments with ligamentocytes of four different donors. Statistic: One sample t-test, two-tailed (comparison with day 0 monolayer) $\left(^{*}\right)$, paired one-way ANOVA (comparison between the groups) (\#), Grubbs test $(\alpha=0.05)$. $p$ values: \#\#\#<0.001, ${ }^{* * * *} / \# \# \#+0.0001$ (A-D).

\subsection{Protein Expression in Ligamentocyte Sheets and Scaffolds Seeded with Them}

Type I collagen and decorin protein expression could be detected in cell sheets and scaffolds seeded with ligamentocyte sheets after 7 and $14 \mathrm{~d}$. It was mostly homogeneously distributed around the cells in the cell sheets with some areas of higher immunoreactivity in cell sheets of day 14 compared to day 7 (Figure 8A-C). 


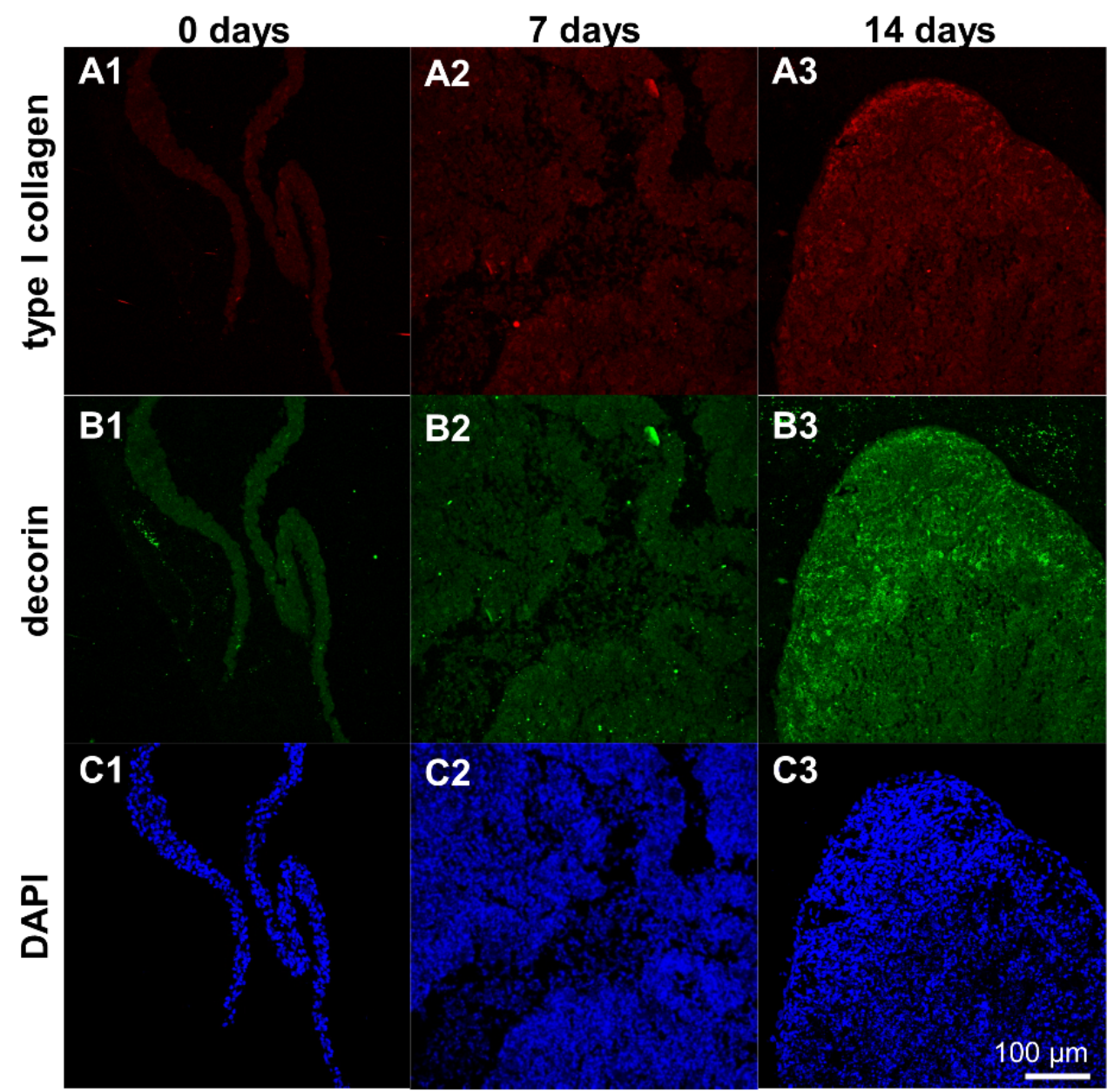

Figure 8. Protein expression of type I collagen and decorin by ligamentocyte sheets released from PGE-coated surfaces after detachment $(0 \mathrm{~d})$ and when cultured for 7 or $14 \mathrm{~d}$. Type I collagen is depicted in red (A1-A3), decorin in green (B1-B3). Ligamentocyte nuclei were counterstained in blue using 4',6-diamidino-2-phenylindole (DAPI) (C1-C3). A view on the sheet is shown by confocal laser scanning microscopy. Scale bar: $100 \mu \mathrm{m}$ (A1-C3).

Type I collagen and decorin protein expression was detectable in the scaffolds seeded with ligamentocyte sheets at both time points of investigation (7 and $14 \mathrm{~d}$ ) with more pronounced immunoreactive areas at day 14 (Figure 9). 


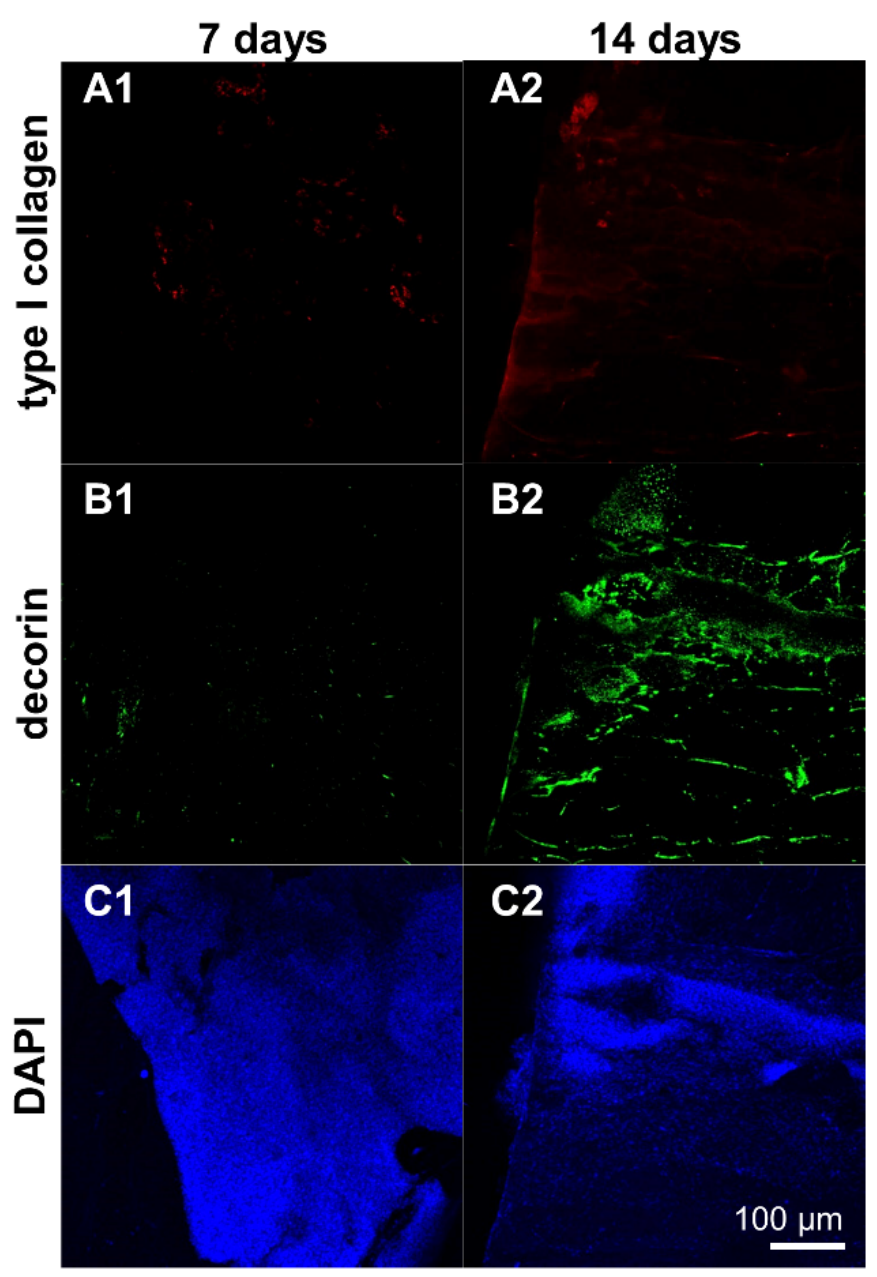

Figure 9. Protein expression of type I collagen and decorin by ligamentocyte sheets released from PGE-coated surfaces and seeded on embroidered scaffolds for 7 or $14 \mathrm{~d}$. Type I collagen is depicted in red (A1,A2), decorin in green (B1,B2). Ligamentocyte nuclei were counterstained in blue using 4',6-diamidino-2-phenylindole (DAPI) $(\mathbf{C 1}, \mathbf{C 2})$. A view on the sheet is shown by confocal laser scanning microscopy. Scale bar: $100 \mu \mathrm{m}$ (A1-C2).

\section{Discussion}

Thermoresponsive surfaces represent versatile tools for diverse medical applications including tissue engineering $[40,41]$. They allow a non-invasive enzyme-free release of the cells from the cell culture dish's surface to gain confluent cell sheets consisting of cells and their own freshly produced ECM [42,43].

Stöbener et al. demonstrated already that cell culture devices coated with the thermoresponsive polymer PGE allowed the production of intact cell sheets from human dermal fibroblasts, human smooth muscle cells from the aorta and human umbilical vein endothelial cells [15], while the sheet detachment from standard polystyrene cell culture devices was not possible under similar conditions [14]. In the present study, lapine cruciate ligamentocyte cell sheets could be produced within $24 \mathrm{~h}$, with both the PGE coating provided by Stöbener et al. [14] and in the most cases also with standard cell culture dishes. However, the time needed to release the sheets was significantly lower with the PGE-coated surfaces, and in some cases sheet production with uncoated polystyrene remained indeed unsuccessful. The required cell density of ligamentocytes needed was higher than that reported by Stöbener et al. for other cell types such as dermal fibroblasts [14]. Ligamentocytes represent the natural cell source for biofabricating ligaments. Nevertheless, in regard to ACL tissue engineering mostly mesenchymal stromal cells (MSCs) or other stem cell species were applied for sheet formation (Table 1). Hence, for ACL ligamentocytes or other tendon- 
derived differentiated cell types only few reference data exist [6,20]. Mitani et al. reported a seeding density of $3 \times 10^{4} \mathrm{ACL}$ ligamentocytes per $\mathrm{cm}^{2}$ but provided no information about the duration of the culture period on the thermoresponsive surface used [6]. Stem cell and progenitor cell-derived sheets can be produced based on a lower cell density (Table 1) and are characterized by abundant ECM $[3,44]$. This observation underlines the dependence of sheet formation on cell density required for each cell type possibly associated with ECM formation capacity, proliferation rate and contact inhibition. Hence, ascorbic acid is often added to stimulate collagen synthesis (Table 1), which stabilizes the cell sheet and allows rapid detachment without impacting the functionality of the coating. The culture medium in the present study contained $25 \mu \mathrm{g} / \mathrm{mL}$ ascorbic acid. The coating in the present study was very durable and could be re-used at least three times for novel sheet formation. This re-use of thermoresponsive materials (poly(NiPAAm-co-DEGMA) was already reported by Nitschke et al. with human corneal endothelial cells [45]. Directly after the $24 \mathrm{~h}$ cell growth phase and before detachment using PBS at AT and body temperature $\left(37^{\circ} \mathrm{C}\right)$ a cell-free margin could be observed at the border of the growth surface of the well near the wall, indicating the start of spontaneous detachment. This cell-free space was significantly larger in the coated compared to the uncoated dishes and a reliable sign for subsequent successful release of intact cell sheets. No intact cell sheet could be harvested if this border was lacking or gaps within the cell layer had occurred. In the present study ligamentocytes seemed to exhibit contractive forces at high cell density. The contraction ability of the cells interacting with each other and their synthesized ECM within the sheet became also evident when comparing the size of the sheets to the initial growth area. The growth area of the well was significantly larger than the released sheets. This shrinkage of the released sheets might also be a correlate of more intensive cell-cell contacts, reorganization of the cytoskeleton, e.g., contractile stress fiber formation and cell interaction with the ECM [46]. In the present study a coherent 3D F-actin network within the cell collective forming a sheet could be observed. F-actin had a rather cortical localization parallel to the interfaces of neighboring cells. Cells in the detached sheets achieved a 3D rounded cell shape resulting in smaller cell diameters compared to the monolayer, which was characterized by larger and highly flattened cells. This switch from a 2D to a 3D cell shape might have contributed to the observed shrinkage of the sheets. Nevertheless, F-actin stress fiber density did not show major differences between ligamentocyte sheets harvested from PGE-coated and uncoated plates.

Histological cross-sections of isolated ligamentocyte sheets stained directly after detachment visualized that the sheets were more than 4 cell diameters thick, hence, underlining their character of a 3D culture. To further investigate the shrinkage after sheet detachment, $\alpha$ SMA expression was visualized directly after sheet harvesting. $\alpha$ SMA represents a mechanosensitive protein, recruited in response to high tension within the stress fibers and responsible for producing high contractile forces by cells $[47,48]$.

Obviously, in contrast to the ligamentocyte monolayers with evenly distributed $\alpha \mathrm{SMA}$, expression of the latter was decreased in the sheets. In many cells of both types of sheets it was only visible as a spot in the perinuclear rER region. This feature might be caused by the loss of cell-substrate contacts, which are probably important as anchor points for force generation, and the fact that possibly cell-cell contacts became much more important for cell communication in freshly released cell sheets. Nevertheless, this aspect has to be investigated in future in more detail. A loss of $\alpha \mathrm{SMA}$ in 3D culture of ligamentocytes (in spheroids and on scaffolds) was shown previously by our research group [49].

After successful release, cell sheets formed spherical cell aggregates during further culturing in a non-adherent cell culture dish. Cruciate ligamentocytes are known to form aggregates when adhesion to a surface is inhibited [50]. To prevent hypoxia and subsequent cell necrosis, less than $250 \mu \mathrm{m}$ thickness is recommended for 3D cultures [46]. Oxygen diffuses only 100-200 $\mu \mathrm{m}$ into spheroidal cell aggregates of different cell types [51]. Despite ligamentocytes derive from a bradytrophic tissue characterized by low oxygen and nutrient exchange, the hypoxia arising in the core of 3D cultures represents a risk factor for impairing 
cell survival [51]. Hence, necrotic zones could be expected in the core of a contracted cell sheet with a diameter of much more than $400-600 \mu \mathrm{m}$ after $7 \mathrm{~d}$ of culturing [51]. They might lead to an enhanced rate of cell death and impair the number of vital cells participating in the 3D culture [50]. However, the cell viability determined was not significantly reduced.

Ligamentocyte sheets cultured for 7 days revealed a significant decrease in the gene expression of typical ECM components by the ligamentocytes such as COLA1 and DCN derived from both surfaces and in regard to TNC only from the uncoated surface in comparison to the monolayer culture at day 0 . The question arises why the monolayer conditions displayed a higher gene expression for COL1A1 and DCN after 7 days when compared to the sheets (significant for the uncoated surfaces). This might be influenced by the fact that the monolayer cells were deprived of their ECM during passaging and expansion, whereas in the sheets the ECM could accumulate as shown by the histology of $7 \mathrm{~d}$. The gene expression profile of typical ligament-related components, the sGAG release and cell viability did not differ between sheets from PGE-coated and uncoated surfaces. Hence the PGE surface might not significantly affect the phenotype of ligamentocytes. Unfortunately, no published reference data are available for ligamentocyte expression profile in sheets released from other thermoresponsive surfaces.

In face of the required biomechanical stability of ACL constructs produced by tissue engineering resilient biomaterials such as PLA or silk fibers, suitable processing techniques are required [52,53]. Cell sheet-derived biomaterial-free constructs might be too weak at all $[33,54]$. Nevertheless, tendon and ligament tissue engineering utilizing cell sheets is an emerging research field $[6,33,54]$. The resistance to tension is substantially lower in constructs produced by cell sheets compared to the native tissue [2,55]. The use of biomechanically suitable scaffolds can overcome this limitation. Embroidered scaffolds manufactured from bio- and cyto-compatible polymers such as P(LA-CL) and PLA could fulfill these requirements, since the embroidery pattern can be adapted to biomechanical demands $[50,56]$. Whether such a scaffold combined with a cell sheet has other biomechanical properties than a scaffold alone remains unclear and should be addressed in future studies. To improve cell adhesion to P(LA-CL)/PLA scaffold surfaces gas fluorination and a native collagen foam cross-linked with HMDI could be used for functionalization, which showed promising results in previous studies [38,57].

The ligamentocyte sheets adhered well to the embroidered P(LA-CL)/PLA scaffold and the cells spread subsequently, whereby the surface of the scaffold covered by cells increased significantly with time, comparing 7 and $14 \mathrm{~d}$. Due to the shrinkage of the sheets placed on the scaffold compared to the detached sheet, after $7 \mathrm{~d}$ less than $5 \%$ of the surface was covered by cells. However, one week later after $14 \mathrm{~d}$ this area was more than duplicated, being more than $10 \%$ mediated by cell spreading and migration onto the fibers of the scaffolds. Ligamentocyte emigration from 3D cultures on a scaffold consisting of synthetic fibers has been described previously [38,49]. The underlying cell signaling processes initiating cell emigration and the possible additional contribution of an enhanced cell proliferation at the interface between sheets and scaffold have to be investigated in future in more detail. Since the viability did not change, longer culturing periods are advised. The ligamentocytes still expressed the main ligament ECM components COL1A1 and DCN on the scaffolds as well as the fibroblast marker TNC and the transcription factor MKX on the gene level. Type I collagen is of central importance for its resiliency in regard to tension [58]. The elevated COL1A1 gene expression, observed on the P(LA-CL)/PLA scaffolds after 14 compared to 7 (scaffold) and $0 \mathrm{~d}$ (monolayer) might show the onset of tissue formation [59]. The protein expression analysis suggests a more pronounced immunoreactivity for type I collagen and decorin at 14 compared to $7 \mathrm{~d}$, which is in accordance with a previous study using the same cell type and similar scaffolds but a cell suspension for seeding and dynamical culture [38]. Decorin is the most important proteoglycan in tendons and ligaments with a life-long expression and a contribution to tendon healing $[60,61]$. It also regulates the collagen fibrillogenesis, the modulation of growth factor activity and cell growth [62], and it was designated as indicator for tendon 
development $[63,64]$. The DCN gene expression in P(LA-CL)/PLA scaffolds seeded with ligamentocyte sheets showed after $14 \mathrm{~d}$ a substantial increase compared to the monolayer at day 0 . In addition, the trend of an increase in decorin protein and gene expression after $14 \mathrm{~d}$ of culture compared to $7 \mathrm{~d}$ became evident. However, the dynamical culture of the same scaffolds seeded with suspended lapine ACL ligamentocytes did not show any increase in DCN gene expression between 7 and $14 \mathrm{~d}$ of culturing [38].

The gene expression of the fibroblast marker TNC, which represents an extracellular glycoprotein, also involved in the maintenance of fibrocartilaginous phenotypes by reducing cell-ECM adhesion [65] and contributing to tissue elasticity [66], was amplified in the scaffolds after 14 compared to 7 (scaffold) and $0 \mathrm{~d}$ (monolayer). The dynamical culture of the same scaffolds with suspended lapine ACL ligamentocytes showed rather a decrease of TNC expression after 14 compared to $7 \mathrm{~d}$ [38].

The ligament-related transcription factor Mohawk, known to be involved in regulation of COL1A1 gene expression [67], increased in the scaffolds between 7 and $14 \mathrm{~d}$. The dynamical culture of the same scaffolds with suspended ligamentocytes showed the same trend in the MKX gene expression [38]. This suggests, together with the increasing expressions of COL1A1, DCN, TNC, MKX from 7 to $14 \mathrm{~d}$, the maintenance of the ligament-related phenotype in the scaffolds. Taken together, the stable expression profile of ligament-related components in the scaffolds seeded with sheets can be highlighted here. The advantage of the novel PGE coating compared to commercially available thermoresponsive surfaces is that it does not affect cell adhesion and phenotype. An interference of the commercially available PNIPAm coating with mouse fibroblast adhesion was reported previously by Becherer et al., [27] and for smooth muscle fibroblasts by Stöbener et al. [15]. Compared to PNIPAm-coated dishes with a detachment time of around $30 \mathrm{~min}$ [6] the detachment time on a PGE-coated surface is substantially shorter $(5 \mathrm{~min})$. The preparation of PGE coatings is very easy and can be done by the researcher on his or her own without sophisticated equipment and at low costs. The devices required include only pipettes, water, ethanol and a simple ultraviolet light lamp.

However, the handling of fragile cell sheets is generally challenging [68-70]. Special devices for a safer transfer of sheets have been recommended [68,71-74] including in situ gelation techniques using gelatin hydrogel carrier membranes [69], commercially available Immobilon-P ${ }^{\circledR}$ and SUPRATHEL ${ }^{\circledR}$ membranes [70] or electrospun fiber mats made of polycaprolactone functionalized with thrombin [75]. Envelopment of scaffolds with cell sheets is indeed time-consuming as experienced in the present study and could be optimized in future using, e.g., hydrogels to achieve an improved surface colonization of the scaffolds. Nevertheless, one future aim is to generate zonal ACL tissues using cell sheet technology. Reconstruction of the ACL requires a stable attachment into the bone [76-78].

Fibrocartilaginous transition and bony zones are necessary at both ends of the tissueengineered ACL construct to mediate firm ligament-to-bone attachment $[77,79]$. Cell sheets could present a strategy of directed seeding of these three cell types (ligamentocytes, fibrochondrocytes and osteoblasts) found within the enthesis on the same scaffold.

\section{Conclusions}

In this study we established pure cruciate ligamentocyte sheets that maintained ligament-related marker expression. Coating of cell culture plates with PGE allowed a very rapid sheet production within $24 \mathrm{~h}$ and the sheet detachment required in mean only $5 \mathrm{~min}$. Primary cells of different cell donors allowed comparable sheet formation underlining the reproducibility. Viability and gene expression profile of ligamentocytes in sheets harvested from PGE-coated plates did not significantly differ from cell performance in sheets harvested from uncoated plates. Moreover, these sheets represent a novel strategy for directed seeding of embroidered scaffolds. The expression of ligament-related components was enhanced on the scaffolds seeded with cell sheets compared to the cell sheets alone and monolayers consisting of cells from the same donor. In this case P(LA-CL)/PLA scaffolds were proven here as suitable to be seeded with cell sheets. Thus, the cell sheet-seeded 
$\mathrm{P}(\mathrm{LA}-\mathrm{CL}) / \mathrm{PLA}$ scaffolds can be used for ACL tissue engineering, improving the biological outcomes of using cell sheets alone.

Author Contributions: Conceptualization, G.S.-T. and M.W.; methodology, I.Z., C.G., D.D.S., J.H., M.S., G.S.-T.; validation, I.Z.; formal analysis, I.Z.; investigation, I.Z., D.D.S., G.S.-T.; resources, I.Z., D.D.S.; data curation, I.Z.; writing—original draft preparation, G.S.-T., I.Z., D.D.S., M.W.; writingreview and editing, I.Z., G.S.-T., D.D.S., M.W., C.G., J.H., A.B., M.M., M.S.; visualization, I.Z., G.S.-T.; supervision, G.S.-T., A.B., M.M., M.W.; project administration, G.S.-T., M.W.; funding acquisition, G.S.-T., M.W. All authors have read and agreed to the published version of the manuscript.

Funding: This research was funded by DFG, grant number SCHU1979/14-1 (Gundula Schulze-Tanzil) and BMBF grant number 13N13523 (Marie Weinhart).

Institutional Review Board Statement: Not applicable.

Informed Consent Statement: Not applicable.

Acknowledgments: The authors would like to thank Benjamin Kohl and Christian Werner for support.

Conflicts of Interest: The authors declare that they have no conflict of interest.

$\begin{array}{ll}\text { Abbreviations } \\ \text { 2D } & \text { two dimensional } \\ \text { 3D } & \text { three-dimensional } \\ \text { AB } & \text { alcian blue } \\ \text { ACL } & \text { anterior cruciate ligament } \\ \text { QSMA } & \text { alpha-smooth muscle actin } \\ \text { AT } & \text { ambient temperature } \\ \text { CL } & \text { Cruciate ligament } \\ \text { CLSM } & \text { confocal laser scanning microscope } \\ \text { COL1A1 } & \text { gene coding for type I collagen } \\ \text { cy3 } & \text { cyanine3 } \\ \text { DAPI } & 4 \text { ',6-diamidino-2-phenylindole } \\ \text { DCN } & \text { gene coding for decorin } \\ \text { DMEM } & \text { Dulbecco's Modified Eagle's Medium } \\ \text { ECM } & \text { extracellular matrix } \\ \text { EDTA } & \text { ethylenediaminetetraacetic acid } \\ \text { EEBP } & 4 \text {-[2-(2,3-epoxypropoxy)ethoxy]benzophenone } \\ \text { EGE } & \text { ethyl glycidyl ether } \\ \text { ETOH } & \text { ethanol } \\ \text { FCS } & \text { fetal calf serum } \\ \text { FDA } & \text { fluorescein diacetate } \\ \text { FILK } & \text { Forschungsinstitut für Leder und Kunststoffbahnen } \\ \text { GME } & \text { glycidyl methyl ether } \\ \text { HE } & \text { hematoxylin-eosin } \\ \text { HMDI } & \text { hexamethylene diisocyanate } \\ \text { Hz } & \text { Herz } \\ \text { L } & \text { lapine } \\ \text { MKX } & \text { gene coding for Mohawk } \\ \text { ML } & \text { monolayer } \\ \text { O.: } & \text { Oryctolagus } \\ \text { P(LA-CL) } & \text { poly(lactic-co- } \varepsilon \text {-caprolactone) } \\ & \end{array}$




$\begin{array}{ll}\text { PBS } & \text { phosphate buffered saline } \\ \text { PFA } & \text { paraformaldehyde } \\ \text { PGE } & \text { poly(glycidyl ether) } \\ \text { PI } & \text { propidium iodide } \\ \text { PLA } & \text { polylactide acid } \\ \text { PNIPAm } & \text { poly(N-isopropylacrylamide) } \\ \text { PVA } & \text { polyvinyl alcohol } \\ \text { SCs } & \text { stem cells } \\ \text { SD } & \text { standard deviation } \\ \text { sGAG } & \text { sulphated glycosaminoglycan } \\ \text { TBS } & \text { TRIS buffered saline } \\ \text { TCPS } & \text { tissue culture polystyrene } \\ \text { TDSC } & \text { tendon-derived stem cells } \\ \text { TNC } & \text { gene coding for tenascin C }\end{array}$

\section{References}

1. Yao, L.; Bestwick, C.S.; Bestwick, L.A.; Maffulli, N.; Aspden, R.M. Phenotypic drift in human tenocyte culture. Tissue Eng. 2006, 12, 1843-1849. [CrossRef]

2. Vaquette, C.; Kumar, P.T.S.; Petcu, E.B.; Ivanovski, S. Combining electrospinning and cell sheet technology for the development of a multiscale tissue engineered ligament construct (TELC). J. Biomed. Mater. Res. Part B Appl. Biomater. 2018, 106, 399-409. [CrossRef] [PubMed]

3. Lui, P.P.Y.; Wong, O.T.; Lee, Y.W. Application of Tendon-Derived Stem Cell Sheet for the Promotion of Graft Healing in Anterior Cruciate Ligament Reconstruction. Am. J. Sports Med. 2014, 42, 681-689. [CrossRef] [PubMed]

4. Ruan, D.; Zhu, T.; Huang, J.; Le, H.; Hu, Y.; Zheng, Z.; Tang, C.; Chen, Y.; Ran, J.; Chen, X.; et al. Knitted Silk-Collagen Scaffold Incorporated with Ligament Stem/Progenitor Cells Sheet for Anterior Cruciate Ligament Reconstruction and Osteoarthritis Prevention. ACS Biomater. Sci. Eng. 2019, 5, 5412-5421. [CrossRef]

5. Kawakami, Y.; Takayama, K.; Matsumoto, T.; Tang, Y.; Wang, B.; Mifune, Y.; Cummins, J.H.; Warth, R.J.; Kuroda, R.; Kurosaka, M.; et al. Anterior Cruciate Ligament-Derived Stem Cells Transduced With BMP2 Accelerate Graft-Bone Integration After ACL Reconstruction. Am. J. Sports Med. 2017, 45, 584-597. [CrossRef] [PubMed]

6. Mitani, G.; Sato, M.; Yamato, M.; Kokubo, M.; Takagaki, T.; Ebihara, G.; Okano, T.; Mochida, J. Potential utility of cell sheets derived from the anterior cruciate ligament and synovium fabricated in temperature-responsive culture dishes. J. Biomed. Mater. Res. Part A 2014, 102, 2927-2933. [CrossRef] [PubMed]

7. Zurina, I.M.; Presniakova, V.S.; Butnaru, D.V.; Svistunov, A.A.; Timashev, P.S.; Rochev, Y.A. Tissue engineering using a combined cell sheet technology and scaffolding approach. Acta Biomater. 2020, 113, 63-83. [CrossRef] [PubMed]

8. Vaquette, C.; Saifzadeh, S.; Farag, A.; Hutmacher, D.; Ivanovski, S. Periodontal Tissue Engineering with a Multiphasic Construct and Cell Sheets. J. Dent. Res. 2019, 98, 673-681. [CrossRef] [PubMed]

9. Vaquette, C.; Fan, W.; Xiao, Y.; Hamlet, S.; Hutmacher, D.W.; Ivanovski, S. A biphasic scaffold design combined with cell sheet technology for simultaneous regeneration of alveolar bone/periodontal ligament complex. Biomaterials 2012, 33, $5560-5573$. [CrossRef]

10. Raju, R.; Oshima, M.; Inoue, M.; Morita, T.; Huijiao, Y.; Waskitho, A.; Baba, O.; Inoue, M.; Matsuka, Y. Three-dimensional periodontal tissue regeneration using a bone-ligament complex cell sheet. Sci. Rep. 2020, 10, 1-16. [CrossRef] [PubMed]

11. Zhang, Q.; Weber, C.; Schubert, U.S.; Hoogenboom, R. Thermoresponsive polymers with lower critical solution temperature: From fundamental aspects and measuring techniques to recommended turbidimetry conditions. Mater. Horizons 2017, 4, 109-116. [CrossRef]

12. Zhao, C.; Ma, Z.; Zhu, X.X. Rational design of thermoresponsive polymers in aqueous solutions: A thermodynamics map. Progress Polym. Sci. 2019, 90, 269-291. [CrossRef]

13. Doberenz, F.; Zeng, K.; Willems, C.; Zhang, K.; Groth, T. Thermoresponsive polymers and their biomedical application in tissue engineering-A review. J. Mater. Chem. B 2020, 8, 607-628. [CrossRef]

14. Stöbener, D.D. Glycidyl Ether-Based Coatings on Polystyrene Culture Substrates for Temperature-Triggered Cell Sheet Fabrication. Ph.D. Thesis, Free University of Berlin, Berlin, Germany, 2018.

15. Stöbener, D.D.; Hoppensack, A.; Scholz, J.; Weinhart, M. Endothelial, smooth muscle and fibroblast cell sheet fabrication from self-assembled thermoresponsive poly(glycidyl ether) brushes. Soft Matter. 2018, 14, 8333-8343. [CrossRef]

16. Tenhu, N.J.A.H. How to manipulate the upper critical solution temperature (UCST)? Polym. Chem. 2017, 8, $220-232$.

17. Osváth, Z.; Iván, B. The Dependence of the Cloud Point, Clearing Point, and Hysteresis of Poly(N-isopropylacrylamide) on Experimental Conditions: The Need for Standardization of Thermoresponsive Transition Determinations. Macromol. Chem. Phys. 2017, 218, 1600470. [CrossRef]

18. Nagase, K.; Yamato, M.; Kanazawa, H.; Okano, T. Poly(N-isopropylacrylamide)-based thermoresponsive surfaces provide new types of biomedical applications. Biomaterials 2018, 153, 27-48. [CrossRef] [PubMed] 
19. Yamada, N.; Okano, T.; Sakai, H.; Karikusa, F.; Sawasaki, Y.; Sakurai, Y. Thermo-responsive polymeric surfaces; control of attachment and detachment of cultured cells. Macromol. Rapid Commun. 1990, 11, 571-576. [CrossRef]

20. Harada, Y.; Mifune, Y.; Inui, A.; Sakata, R.; Muto, T.; Takase, F.; Ueda, Y.; Kataoka, T.; Kokubu, T.; Kuroda, R.; et al. Rotator cuff repair using cell sheets derived from human rotator cuff in a rat model. J. Orthop. Res. 2017, 35, 289-296. [CrossRef] [PubMed]

21. Okano, T.; Yamada, N.; Okuhara, M.; Sakai, H.; Sakurai, Y. Mechanism of cell detachment from temperature-modulated, hydrophilic-hydrophobic polymer surfaces. Biomaterials 1995, 16, 297-303. [CrossRef]

22. Weinhart, M.; Becherer, T.; Haag, R. Switchable, biocompatible surfaces based on glycerol copolymers. Chem. Commun. 2010, 47, 1553-1555. [CrossRef]

23. Heinen, S.; Rackow, S.; Schäfer, A.; Weinhart, M. A Perfect Match: Fast and Truly Random Copolymerization of Glycidyl Ether Monomers to Thermoresponsive Copolymers. Macromolecules 2017, 50, 44-53. [CrossRef]

24. Thomas, A.; Müller, S.S.; Frey, H. Beyond Poly(ethylene glycol): Linear Polyglycerol as a Multifunctional Polyether for Biomedical and Pharmaceutical Applications. Biomacromolecules 2014, 15, 1935-1954. [CrossRef] [PubMed]

25. Herzberger, J.; Niederer, K.; Pohlit, H.; Seiwert, J.; Worm, M.; Wurm, F.R.; Frey, H. Polymerization of Ethylene Oxide, Propylene Oxide, and Other Alkylene Oxides: Synthesis, Novel Polymer Architectures, and Bioconjugation. Chem. Rev. 2016, 116, $2170-2243$. [CrossRef] [PubMed]

26. Gerecke, C.; Edlich, A.; Giulbudagian, M.; Schumacher, F.; Zhang, N.; Said, A.; Yealland, G.; Lohan, S.B.; Neumann, F.; Meinke, M.C.; et al. Biocompatibility and characterization of polyglycerol-based thermoresponsive nanogels designed as novel drug-delivery systems and their intracellular localization in keratinocytes. Nanotoxicology 2017, 11, 267-277. [CrossRef]

27. Becherer, T.; Heinen, S.; Wei, Q.; Haag, R.; Weinhart, M. In-depth analysis of switchable glycerol based polymeric coatings for cell sheet engineering. Acta Biomater. 2015, 25, 43-55. [CrossRef]

28. Heinen, S.; Cuellar-Camacho, J.L.; Weinhart, M. Thermoresponsive poly(glycidyl ether) brushes on gold: Surface engineering parameters and their implication for cell sheet fabrication. Acta Biomater. 2017, 59, 117-128. [CrossRef]

29. Heinen, S.; Rackow, S.; Cuellar-Camacho, J.L.; Donskyi, I.S.; Unger, W.E.S.; Weinhart, M. Transfer of functional thermoresponsive poly(glycidyl ether) coatings for cell sheet fabrication from gold to glass surfaces. J. Mater. Chem. B 2018, 6, 1489-1500. [CrossRef] [PubMed]

30. Stöbener, D.D.; Weinhart, M. Thermoresponsive Poly(glycidyl ether) Brush Coatings on Various Tissue Culture Substrates-How Block Copolymer Design and Substrate Material Govern Self-Assembly and Phase Transition. Polymers 2020, 12, 1899. [CrossRef]

31. Hsieh, C.-F.; Yan, Z.; Schumann, R.G.; Milz, S.; Pfeifer, C.G.; Schieker, M.; Docheva, D. In Vitro Comparison of 2D-Cell Culture and 3D-Cell Sheets of Scleraxis-Programmed Bone Marrow Derived Mesenchymal Stem Cells to Primary Tendon Stem/Progenitor Cells for Tendon Repair. Int. J. Mol. Sci. 2018, 19, 2272. [CrossRef]

32. Yan, Z.; Yin, H.; Brochhausen, C.; Pfeifer, C.G.; Alt, V.; Docheva, D. Aged Tendon Stem/Progenitor Cells Are Less Competent to Form 3D Tendon Organoids Due to Cell Autonomous and Matrix Production Deficits. Front. Bioeng. Biotechnol. 2020, $8,406$. [CrossRef]

33. Ni, M.; Rui, Y.F.; Tan, Q.; Liu, Y.; Xu, L.L.; Chan, K.M.; Wang, Y.; Li, G. Engineered scaffold-free tendon tissue produced by tendon-derived stem cells. Biomaterials 2013, 34, 2024-2037. [CrossRef]

34. Shen, H.; Kormpakis, I.; Havlioglu, N.; Linderman, S.W.; Sakiyama-Elbert, S.E.; Erickson, I.E.; Zarembinski, T.; Silva, M.J.; Gelberman, R.H.; Thomopoulos, S. The effect of mesenchymal stromal cell sheets on the inflammatory stage of flexor tendon healing. Stem Cell Res. Ther. 2016, 7, 1-13. [CrossRef]

35. Gonçalves, A.I.; Rodrigues, M.T.; Gomes, M.E. Tissue-engineered magnetic cell sheet patches for advanced strategies in tendon regeneration. Acta Biomater. 2017, 63, 110-122. [CrossRef]

36. Mifune, Y.; Matsumoto, T.; Takayama, K.; Terada, S.; Sekiya, N.; Kuroda, R.; Kurosaka, M.; Fu, F.H.; Huard, J. Tendon graft revitalization using adult anterior cruciate ligament (ACL)-derived CD34+ cell sheets for ACL reconstruction. Biomaterials 2013, 34, 5476-5487. [CrossRef]

37. Komatsu, I.; Wang, J.H.-C.; Iwasaki, K.; Shimizu, T.; Okano, T. The effect of tendon stem/progenitor cell (TSC) sheet on the early tendon healing in a rat Achilles tendon injury model. Acta Biomater. 2016, 42, 136-146. [CrossRef] [PubMed]

38. Gögele, C.; Hahn, J.; Elschner, C.; Breier, A.; Schropfer, M.; Prade, I.; Meyer, M.; Schulze-Tanzil, G. Enhanced Growth of Lapine Anterior Cruciate Ligament-Derived Fibroblasts on Scaffolds Embroidered from Poly(l-lactide-co-epsilon-caprolactone) and Polylactic Acid Threads Functionalized by Fluorination and Hexamethylene Diisocyanate Cross-Linked Collagen Foams. Int. J. Mol. Sci. 2020, 21, 1132.

39. Simon, P. Q-Gene: Processing quantitative real-time RT-PCR data. Bioinformatics 2003, 19, 1439-1440. [CrossRef] [PubMed]

40. Wang, J.; Zhang, R.; Shen, Y.; Xu, C.; Qi, S.; Lu, L.; Wang, R.; Xu, Y. Recent advances in cell sheet technology for periodontal regeneration. Curr. Stem Cell Res. Ther. 2014, 9, 162-173. [CrossRef] [PubMed]

41. Ward, M.A.; Georgiou, T.K. Thermoresponsive Polymers for Biomedical Applications. Polymers 2011, 3, 1215-1242. [CrossRef]

42. Reed, J.A.; Lucero, A.E.; Hu, S.; Ista, L.K.; Bore, M.T.; López, G.P.; Canavan, H.E. A Low-Cost, Rapid Deposition Method for "Smart" Films: Applications in Mammalian Cell Release. ACS Appl. Mater. Interfaces 2010, 2, 1048-1051. [CrossRef] [PubMed]

43. Kumashiro, Y.; Yamato, M.; Okano, T. Cell Attachment-Detachment Control on Temperature-Responsive Thin Surfaces for Novel Tissue Engineering. Ann. Biomed. Eng. 2010, 38, 1977-1988. [CrossRef] [PubMed]

44. Neo, P.Y.; Teh, T.K.H.; Tay, A.S.R.; Asuncion, M.C.T.; Png, S.N.; Toh, S.L.; Goh, J.C.-H. Stem cell-derived cell-sheets for connective tissue engineering. Connect. Tissue Res. 2016, 57, 428-442. [CrossRef] [PubMed] 
45. Nitschke, M.; Gramm, S.; Gotze, T.; Valtink, M.; Drichel, J.; Voit, B.; Engelmann, K.; Werner, C. Thermo-responsive poly(NiPAAmco-DEGMA) substrates for gentle harvest of human corneal endothelial cell sheets. J. Biomed. Mater. Res. A 2007, 80, $1003-1010$. [CrossRef]

46. Griffith, L.G.; Swartz, M.A. Capturing complex 3D tissue physiology in vitro. Nat. Rev. Mol. Cell. Biol. 2006, 7, 211-224. [CrossRef]

47. Hinz, B.; Celetta, G.; Tomasek, J.J.; Gabbiani, G.; Chaponnier, C. Alpha-Smooth Muscle Actin Expression Upregulates Fibroblast Contractile Activity. Mol. Biol. Cell 2001, 12, 2730-2741. [CrossRef] [PubMed]

48. Hinz, B.; Gabbiani, G.; Chaponnier, C. The NH2-terminal peptide of $\alpha$-smooth muscle actin inhibits force generation by the myofibroblast in vitro and in vivo. J. Cell Biol. 2002, 157, 657-663. [CrossRef] [PubMed]

49. Schwarz, S.; Gögele, C.; Ondruschka, B.; Hammer, N.; Kohl, B.; Schulze-Tanzil, G. Migrating Myofibroblastic Iliotibial BandDerived Fibroblasts Represent a Promising Cell Source for Ligament Reconstruction. Int. J. Mol. Sci. 2019, 20, 1972. [CrossRef]

50. Hoyer, M.; Meier, C.; Breier, A.; Hahner, J.; Heinrich, G.; Drechsel, N.; Meyer, M.; Rentsch, C.; Garbe, L.-A.; Ertel, W.; et al. In vitro characterization of self-assembled anterior cruciate ligament cell spheroids for ligament tissue engineering. Histochem. Cell Biol. 2015, 143, 289-300. [CrossRef]

51. Anada, T.; Fukuda, J.; Sai, Y.; Suzuki, O. An oxygen-permeable spheroid culture system for the prevention of central hypoxia and necrosis of spheroids. Biomaterials 2012, 33, 8430-8441. [CrossRef]

52. Altman, G.H.; Horan, R.L.; Lu, H.H.; Moreau, J.; Martin, I.; Richmond, J.C.; Kaplan, D.L. Silk matrix for tissue engineered anterior cruciate ligaments. Biomaterials 2002, 23, 4131-4141. [CrossRef]

53. Freeman, J.W.; Woods, M.D.; Laurencin, C.T. Tissue engineering of the anterior cruciate ligament using a braid-twist scaffold design. J. Biomech. 2007, 40, 2029-2036. [CrossRef]

54. Mahalingam, V.D.; Behbahani-Nejad, N.; Horine, S.V.; Olsen, T.J.; Smietana, M.J.; Wojtys, E.M.; Wellik, D.M.; Arruda, E.M.; Larkin, L.M. Allogeneic Versus Autologous Derived Cell Sources for Use in Engineered Bone-Ligament-Bone Grafts in Sheep Anterior Cruciate Ligament Repair. Tissue Eng. Part A 2015, 21, 1047-1054. [CrossRef]

55. Calve, S.; Lytle, I.F.; Grosh, K.; Brown, D.L.; Arruda, E.M. Implantation increases tensile strength and collagen content of self-assembled tendon constructs. J. Appl. Physiol. 2010, 108, 875-881. [CrossRef] [PubMed]

56. Hahn, J.; Schulze-Tanzil, G.; Schropfer, M.; Meyer, M.; Gogele, C.; Hoyer, M.; Spickenheuer, A.; Heinrich, G.; Breier, A. Viscoelastic Behavior of Embroidered Scaffolds for ACL Tissue Engineering Made of PLA and P(LA-CL) After In Vitro Degradation. Int. J. Mol. Sci. 2019, 20, 4655. [CrossRef]

57. Schroepfer, M.; Junghans, F.; Voigt, D.; Meyer, M.; Breier, A.; Schulze-Tanzil, G.; Prade, I. Gas-Phase Fluorination on PLA Improves Cell Adhesion and Spreading. ACS Omega 2020, 5, 5498-5507. [CrossRef] [PubMed]

58. Kannus, P. Structure of the tendon connective tissue. Scand. J. Med. Sci. Sports 2000, 10, 312-320. [CrossRef] [PubMed]

59. Fan, H.; Liu, H.; Wong, E.J.; Toh, S.L.; Goh, J.C. In vivo study of anterior cruciate ligament regeneration using mesenchymal stem cells and silk scaffold. Biomaterials 2008, 29, 3324-3337. [CrossRef]

60. Dunkman, A.A.; Buckley, M.R.; Mienaltowski, M.J.; Adams, S.M.; Thomas, S.J.; Satchell, L.; Kumar, A.; Pathmanathan, L.; Beason, D.P.; Iozzo, R.V.; et al. The Tendon Injury Response is Influenced by Decorin and Biglycan. Ann. Biomed. Eng. 2014, 42, 619-630. [CrossRef]

61. Kavanagh, E.; Ashhurst, D.E. Distribution of biglycan and decorin in collateral and cruciate ligaments and menisci of the rabbit knee joint. J. Histochem. Cytochem. 2001, 49, 877-885. [CrossRef] [PubMed]

62. Weber, I.T.; Harrison, R.W.; Iozzo, R.V. Model Structure of Decorin and Implications for Collagen Fibrillogenesis. J. Biol. Chem. 1996, 271, 31767-31770. [CrossRef]

63. Juneja, S.C.; Veillette, C. Defects in Tendon, Ligament, and Enthesis in Response to Genetic Alterations in Key Proteoglycans and Glycoproteins: A Review. Arthritis 2013, 2013, 1-30. [CrossRef]

64. Thorpe, C.T.; Birch, H.L.; Clegg, P.D.; Screen, H.R. The role of the non-collagenous matrix in tendon function. Int. J. Exp. Pathol. 2013, 94, 248-259. [CrossRef]

65. Mehr, D.; Pardubsky, P.D.; Martin, J.A.; Buckwalter, J.A. Tenascin-C in tendon regions subjected to compression. J. Orthop. Res. 2000, 18, 537-545. [CrossRef]

66. Järvinen, T.L.N.; Józsa, L.; Kannus, P.; Hurme, T.; Kvist, M.; Pelto-Huikko, M.; Kalimo, H.; Järvinen, M. Mechanical loading regulates the expression of tenascin- $\mathrm{C}$ in the myotendinous junction and tendon but does not induce de novo synthesis in the skeletal muscle. J. Cell Sci. 2003, 116, 857-866. [CrossRef] [PubMed]

67. Ito, Y.; Toriuchi, N.; Yoshitaka, T.; Ueno-Kudoh, H.; Sato, T.; Yokoyama, S.; Nishida, K.; Akimoto, T.; Takahashi, M.; Miyaki, S.; et al. The Mohawk homeobox gene is a critical regulator of tendon differentiation. Proc. Natl. Acad. Sci. USA 2010, 107, 10538-10542. [CrossRef] [PubMed]

68. Tadakuma, K.; Tanaka, N.; Haraguchi, Y.; Higashimori, M.; Kaneko, M.; Shimizu, T.; Yamato, M.; Okano, T. A device for the rapid transfer/transplantation of living cell sheets with the absence of cell damage. Biomaterials 2013, 34, 9018-9025. [CrossRef] [PubMed]

69. Akimoto, J.; Arauchi, A.; Nakayama, M.; Kanaya, R.; Iwase, Y.; Takagi, S.; Yamato, M.; Okano, T. Facile cell sheet manipulation and transplantation by using in situ gelation method. J. Biomed. Mater. Res. B Appl. Biomater. 2014, 102, 1659-1668. [CrossRef] [PubMed] 
70. Kawecki, M.; Kraut, M.; Klama-Baryła, A.; Łabuś, W.; Kitala, D.; Nowak, M.; Glik, J.; Sieroń, A.L.; Utrata-Wesołek, A.; Trzebicka, B.; et al. Transfer of fibroblast sheets cultured on thermoresponsive dishes with membranes. J. Mater. Sci. Mater. Med. 2016, 27, 1-12. [CrossRef]

71. Nishida, K.; Yamato, M.; Hayashida, Y.; Watanabe, K.; Yamamoto, K.; Adachi, E.; Nagai, S.; Kikuchi, A.; Maeda, N.; Watanabe, H.; et al. Corneal Reconstruction with Tissue-Engineered Cell Sheets Composed of Autologous Oral Mucosal Epithelium. N. Engl. J. Med. 2004, 351, 1187-1196. [CrossRef] [PubMed]

72. Ohki, T.; Yamato, M.; Ota, M.; Takagi, R.; Murakami, D.; Kondo, M.; Sasaki, R.; Namiki, H.; Okano, T.; Yamamoto, M. Prevention of Esophageal Stricture After Endoscopic Submucosal Dissection Using Tissue-Engineered Cell Sheets. Gastroenterology 2012, 143, 582-588.e2. [CrossRef]

73. Sawa, Y.; Miyagawa, S.; Sakaguchi, T.; Fujita, T.; Matsuyama, A.; Saito, A.; Shimizu, T.; Okano, T. Tissue engineered myoblast sheets improved cardiac function sufficiently to discontinue LVAS in a patient with DCM: Report of a case. Surg. Today 2011, 42, 181-184. [CrossRef]

74. Sasagawa, T.; Shimizu, T.; Sekiya, S.; Haraguchi, Y.; Yamato, M.; Sawa, Y.; Okano, T. Design of prevascularized three-dimensional cell-dense tissues using a cell sheet stacking manipulation technology. Biomaterials 2010, 31, 1646-1654. [CrossRef] [PubMed]

75. Madathil, B.K.; Sundaran, S.P.; Kumary, T.V.; Bhatt, A.; Kumar, P.R.A. Biofunctionalised Polycaprolactone Fibrous Mat as a Transfer Tool for Cell Sheet Engineering. Fibers Polym. 2017, 18, 2094-2101. [CrossRef]

76. Ekdahl, M.; Wang, J.H.-C.; Ronga, M.; Fu, F.H. Graft healing in anterior cruciate ligament reconstruction. Knee Surg. Sports Traumatol. Arthrosc. 2008, 16, 935-947. [CrossRef]

77. Lu, H.H.; Subramony, S.D.; Boushell, M.K.; Zhang, X. Tissue Engineering Strategies for the Regeneration of Orthopedic Interfaces. Ann. Biomed. Eng. 2010, 38, 2142-2154. [CrossRef] [PubMed]

78. Smith, L.; Xia, Y.; Galatz, L.M.; Genin, G.M.; Thomopoulos, S. Tissue-engineering strategies for the tendon/ligament-to-bone insertion. Connect. Tissue Res. 2012, 53, 95-105. [CrossRef]

79. Benjamin, M.; Toumi, H.; Ralphs, J.R.; Bydder, G.; Best, T.M.; Milz, S. Where tendons and ligaments meet bone: Attachment sites ('entheses') in relation to exercise and/or mechanical load. J. Anat. 2006, 208, 471-490. [CrossRef] [PubMed] 